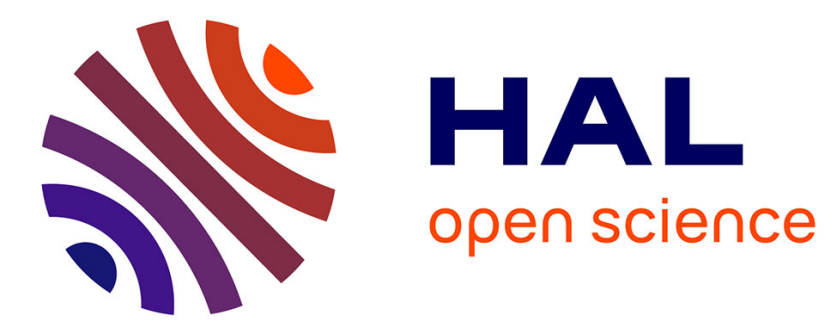

\title{
Cyclic cis-1,3-Diamines Derived from Bicyclic Hydrazines: Synthesis and Applications
}

Claire Fleurisson, Erica Benedetti, Laurent Micouin

\section{To cite this version:}

Claire Fleurisson, Erica Benedetti, Laurent Micouin. Cyclic cis-1,3-Diamines Derived from Bicyclic Hydrazines: Synthesis and Applications. SYNLETT, 2020, 10.1055/s-0040-1707324 . hal-03003668

\section{HAL Id: hal-03003668 https://hal.science/hal-03003668}

Submitted on 13 Nov 2020

HAL is a multi-disciplinary open access archive for the deposit and dissemination of scientific research documents, whether they are published or not. The documents may come from teaching and research institutions in France or abroad, or from public or private research centers.
L'archive ouverte pluridisciplinaire HAL, est destinée au dépôt et à la diffusion de documents scientifiques de niveau recherche, publiés ou non, émanant des établissements d'enseignement et de recherche français ou étrangers, des laboratoires publics ou privés. 


\section{Cyclic cis-1,3-diamines derived from bicyclic hydrazines: Synthesis and applications}

\author{
Claire Fleurisson $^{\mathrm{a}}$ \\ Erica Benedetti*a \\ Laurent Micouin*a \\ a Laboratoire de Chimie et Biochimie Pharmacologiques et \\ Toxicologiques - UMR8601 CNRS Université de Paris, 45 rue \\ des Saints Pères, 75006 Paris (France). \\ erica.benedetti@parisdescartes.fr \\ laurent.micouin@parisdescartes.f
}

Click here to insert a dedication

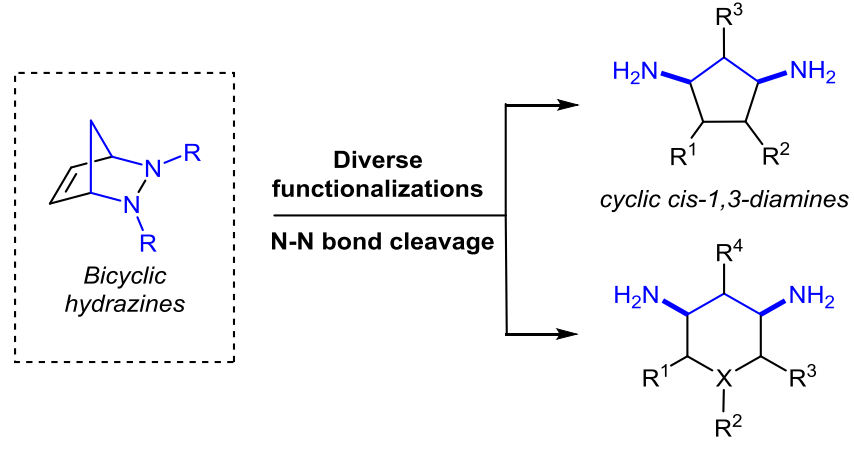

\begin{tabular}{|c|c|}
\hline \multicolumn{2}{|c|}{$\begin{array}{l}\text { Received: } \\
\text { Accepted: } \\
\text { Published online: } \\
\text { DOI: } \\
\end{array}$} \\
\hline \multicolumn{2}{|c|}{$\begin{array}{l}\text { Abstract Cyclic cis-1,3-diamines are versatile building blocks frequently } \\
\text { found in natural molecules or biologically active compounds. In comparison } \\
\text { with widely studied 1,2-diamines, and despite their chemical similarity, 1,3- } \\
\text { diamines have been investigated less intensively probably because of a lack } \\
\text { of general synthetic procedures giving access to these compounds with } \\
\text { good levels of chemo-, regio- and stereocontrol. In this account we will give } \\
\text { a general overview of the biological interest of cyclic cis-1,3-diamines. We } \\
\text { will then describe the synthesis and potential applications of these } \\
\text { compounds with a particular focus on the work realized in our laboratory. }\end{array}$} \\
\hline 1 & Introduction \\
\hline 2 & Biological relevance of the cis-1,3-diamine motif \\
\hline 3 & Classical synthetic strategies towards cis-1,3-diamines \\
\hline 4 & $\begin{array}{l}\mathrm{N}-\mathrm{N} \text { bond cleavage of bicyclic hydrazines: a versatile method to } \\
\text { access cis-1,3-diamines }\end{array}$ \\
\hline 4.1 & Preparation of five-membered cyclic cis-1,3-diaminoalcohols \\
\hline 4.2 & Access to fluorinated 1,3-cis-diaminocyclopentanes \\
\hline 4.3 & Synthesis of cis-1,3-diaminocyclohexitols \\
\hline 4.4 & Formation of cyclic cis-3,5-diamino-piperidines \\
\hline 5 & Applications of cyclic cis-1,3-diamines \\
\hline 5.1 & Small molecular RNA binders \\
\hline & Fluorinated 1,3 diamino cyclopentanes as NMR probes \\
\hline & Concluding remarks \\
\hline \multicolumn{2}{|c|}{$\begin{array}{l}\text { Key words cyclic cis-1,3-diamines; bicyclic hydrazines; fragments RNA } \\
\text { ligands and probes; N-N bond cleavage; hydroxylation; fluorination; } \\
\text { reductive amination }\end{array}$} \\
\hline
\end{tabular}

\section{Introduction}

Although cyclic 1,2-diamine moieties are recognized as important motives commonly used as building blocks in synthetic chemistry or as ligands in catalysis, ${ }^{1}$ their cyclic 1,3 diamine analogues have received much less attention. ${ }^{2}$ As a matter of fact, there is still a need for diversity-oriented general procedures providing practical access to cyclic 1,3diamines with good regio- and stereo-control. This lack of general methods, compared to the variety of strategies developed to access the cyclic 1,2-diamine motif, limits considerably the applications of these compounds in different research fields. Even today, 1,3-diamine containing substrates can therefore be considered important targets in organic chemistry.

Since the early 2000s, our group has been interested in the design of efficient stereoselective routes to 1,3-diamines, with a particular attention to five- and six-membered cyclic compounds showing cis-substitution patterns (Figure 1). Our original goal was to explore the chemical space of these motives, regardless of their potential applications. The challenge was mostly synthetic : how to install a 1,3 diamine motif onto a functionalized five or six-membered ring, in a simple and versatile manner, with a control of the relative, and/or absolute configuration of the stereogenic centers of these densely functionalized scaffolds. Application of these synthetic methods for the design of compounds with interesting properties (mostly biological ones) has also been the focus of our studies during the last ten years.<smiles>[R]C1C([R])C(N)C([R])C1N</smiles>

5-membered rings<smiles>[R]C1C([R])C(N)[Y]([R])([R])C([R])C1N</smiles>

6-membered rings
$R^{1}, R^{2}, R^{3}, R^{4}=H, O H, O R, C O R, A r$, halogen..

$$
\mathrm{X}=\mathrm{C}, \mathrm{N}
$$

Figure 1 General structure of five- and six-membered cyclic cis-1,3-diamines

In this account article we will firstly present the biological relevance of cyclic cis-1,3-diamines. We will also briefly describe the few synthetic approaches that can be followed to access these systems. We will then report our efforts towards the development of new general methods for preparing such derivatives on synthetically useful scales via a key strategy involving the $\mathrm{N}-\mathrm{N}$ bond cleavage of bicyclic hydrazines. We will finally describe the use of the cyclic cis-1,3-diamine compounds synthesized in our laboratory as RNA binders and probes. 


\section{Biological relevance of cyclic cis-1,3-diamines}

Various substrates incorporating five-membered cyclic cis-1,3 diamine moieties have been reported to possess interesting biological activities. ${ }^{3}$ Some selected examples are described in Figure 2, and include compounds showing antifungal, ${ }^{4}$ analgesic or anti-inflammatory activities ${ }^{5}$ as well as potential therapeutic agents against different human diseases. Among them figure a melanin-concentrating hormone (MCH) receptor antagonist that may be used for the treatment of obesity and other metabolic syndromes, ${ }^{6}$ mammalian Janus Kinase 1 (JAK1) inhibitors which could be employed to cure patients affected by myelofibrosis, ${ }^{7}$ and a neuronal nitric oxide synthase (NOSs) inhibitor that may help to prevent neurodegenerative conditions such as rheumatoid arthritis, Alzheimer's disease, and Parkinson's disease. ${ }^{8}$ Pyrimidine carbocyclic nucleosides have finally been reported to possess interesting tumor cell growth inhibitory activities (Figure 2 ). ${ }^{9}$

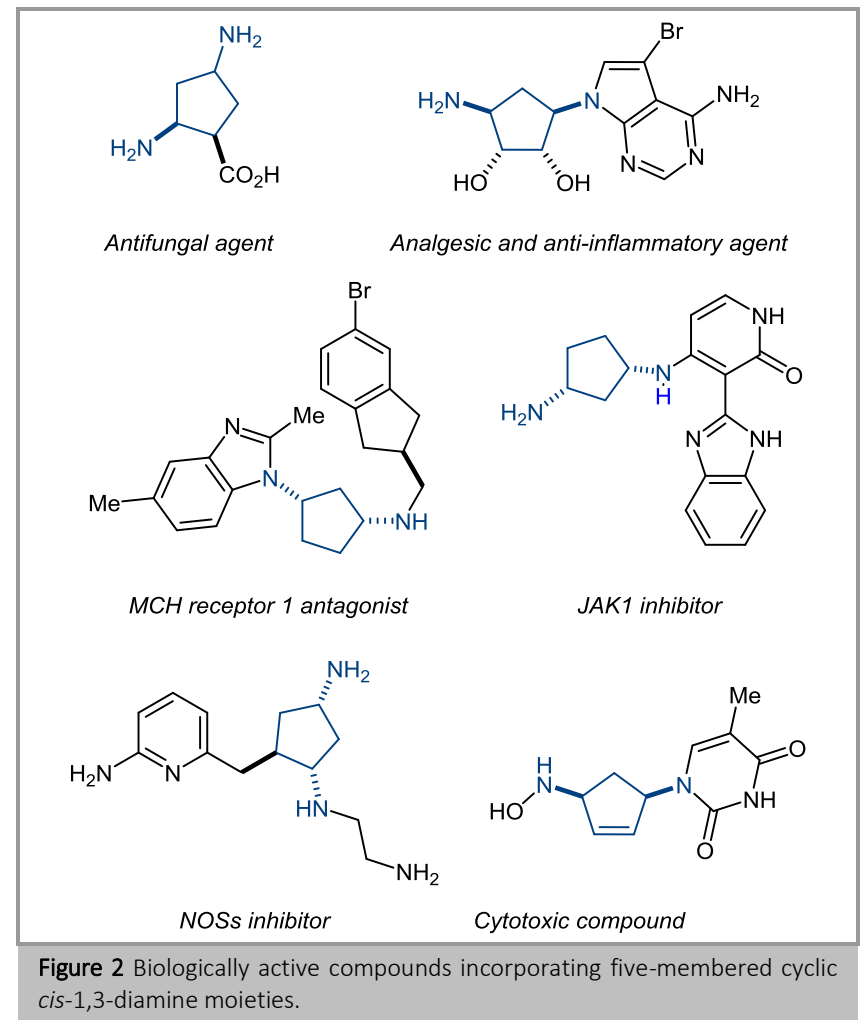

Six-membered cyclic cis-1,3-diamine-containing molecules may also present intriguing biological properties, and many of these compounds are, for this reason, described in patent applications..$^{10} \mathrm{Few}$ examples of such substrates are depicted in Figure 3, and include a dipeptidyl peptidase-4 (DPP-4) inhibitor useful for the treatment of type 2 diabetes, ${ }^{11}$ a protein kinase modulator, ${ }^{12}$ as well as a spleen tyrosine kinase (Syk) inhibitor that may serve to treat inflammatory and autoimmune disorders. ${ }^{13}$ In addition, sugar derivatives showing the six-membered cyclic cis-1,3-diamine motif have been used to develop stimuli-responsive liposomes for drug delivery (Figure 3). ${ }^{14}$

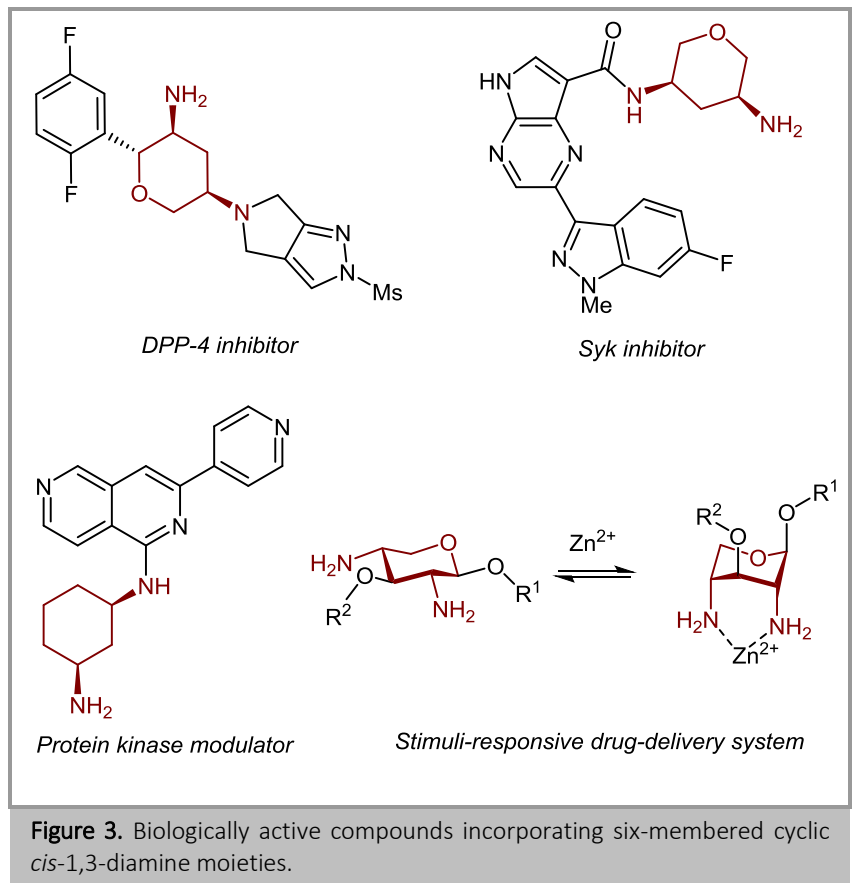

Aminoglycosides irreversibly bind to the $16 \mathrm{~S}$ ribosomal RNA of prokaryotes and prevent bacterial protein synthesis. Extensive studies including NMR investigations ${ }^{15}$ and X-ray crystallographic studies ${ }^{16}$ have highlighted the key interactions provided by the cis 1,3 diamine motif present in all these natural products. Several analogues of the aminoglycoside antibiotics, and in particular of their central core (2-DOS, Figure 4), have been reported over the years. As their parent compounds, these derivatives can show interesting antibacterial properties (Figure 4). ${ }^{17}$

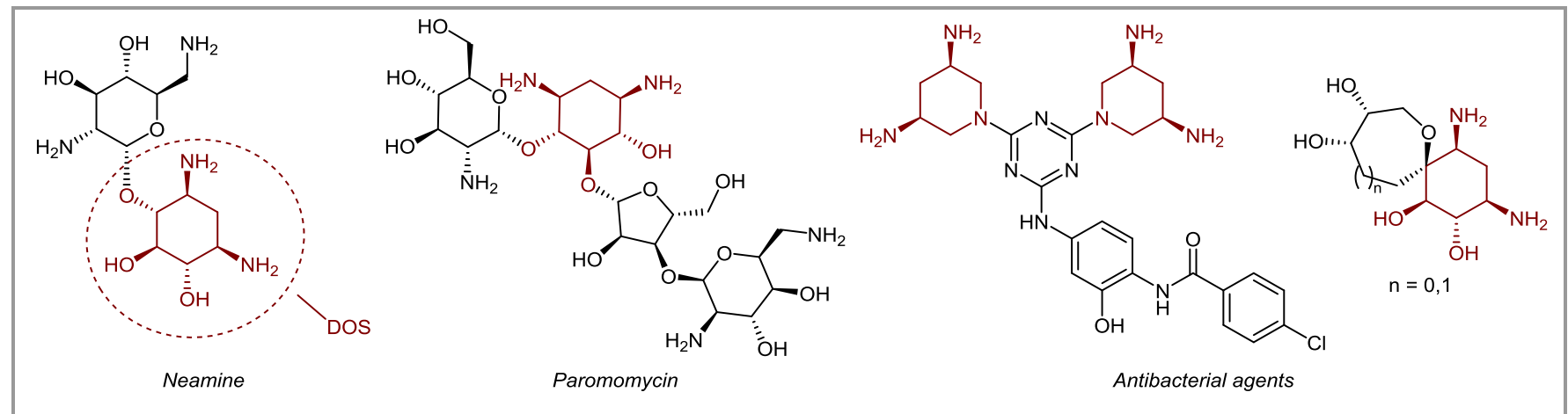

Figure 4 Biologically active compounds incorporating six-membered cyclic cis-1,3-diamine moieties. 


\section{Classical synthetic strategies towards cis-1,3- diamines}

Over the years, cyclic cis-1,3-diamines have been prepared following various approaches. In many cases, different strategies have been used to introduce the amine functionalities onto the desired compounds, one after the other, using linear pathways that require two or more consecutive synthetic steps. The most commonly used methods to achieve these syntheses include epoxide ring-opening reactions, ${ }^{18}$ nucleophilic substitutions, ${ }^{3 \mathrm{~b}, 19}$ palladium-catalyzed allylic aminations, ${ }^{20}$ oxime reductions, ${ }^{19 c, 21}$ Curtius rearrangements, ${ }^{22}$ intramolecular Henry reactions, ${ }^{23}$ ring opening of cyclic sulfates, ${ }^{24}$ and the reduction of aromatic nitro compounds 25 (Figure 5).

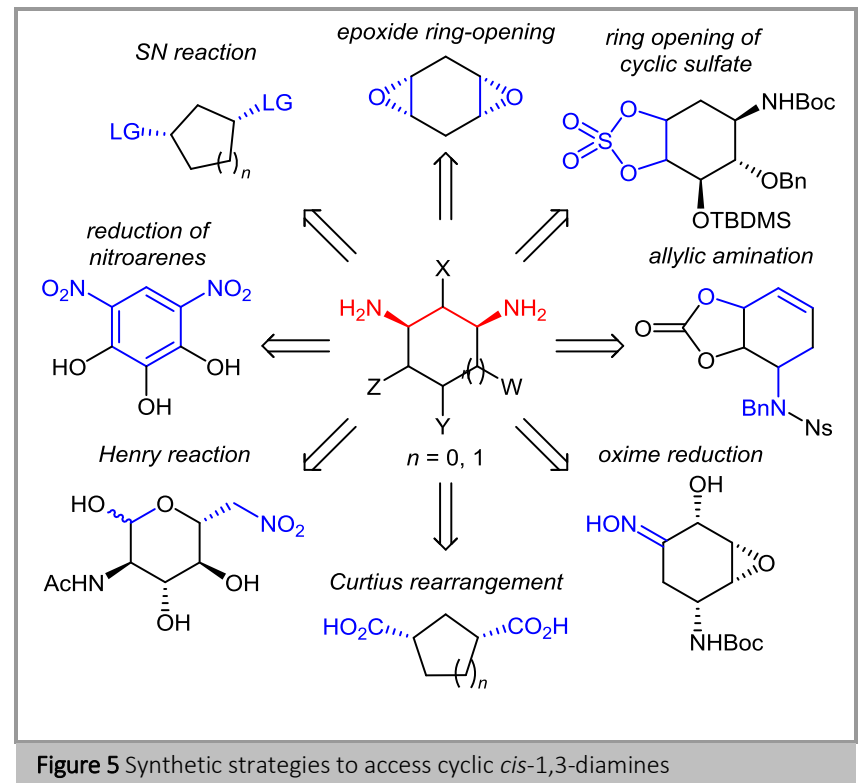

Interestingly, only few of these methods enable to simultaneously install the two amino groups in a single synthetic step.

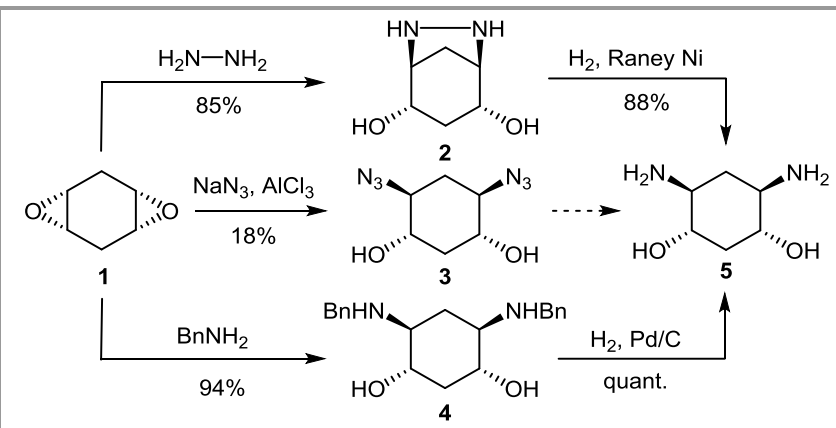

Scheme 1 Examples of epoxide ring-opening reactions

Epoxide ring-opening reactions in the presence of hydrazine, ${ }^{26}$ benzylamine ${ }^{27}$ or sodium azide ${ }^{28}$ can for example be used to form six membered cyclic cis-1,3-diamines after a simple reduction of the reaction products (Scheme 1). Nucleophilic substitutions have been successfully employed to introduce two nitrogen-containing functional groups at once, both on five- 29 and six-membered cyclic compounds (Scheme 2). ${ }^{30}$

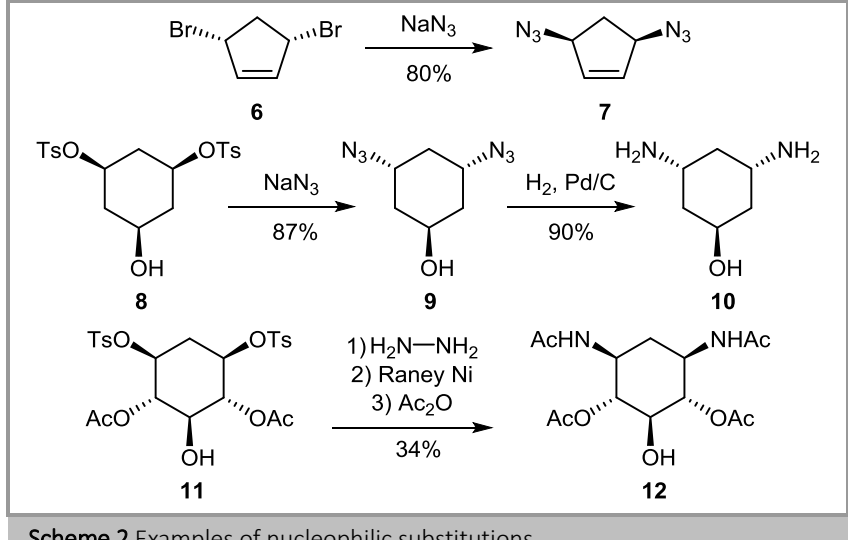

Scheme 2 Examples of nucleophilic substitutions

Examples of oxime reductions ${ }^{31}$ and Curtius rearrangements ${ }^{32}$ have also been reported as ways to functionalize both five- and six-membered rings with two amino groups at the same time (Scheme 3). In some cases, however, the former method does not allow to control the selectivity of the reactions and mixtures of stereoisomers (cis- an trans- 1,3 diamines) are obtained. ${ }^{31}$

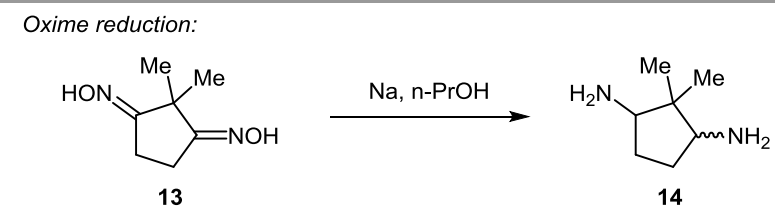

Curtius rearrangements:

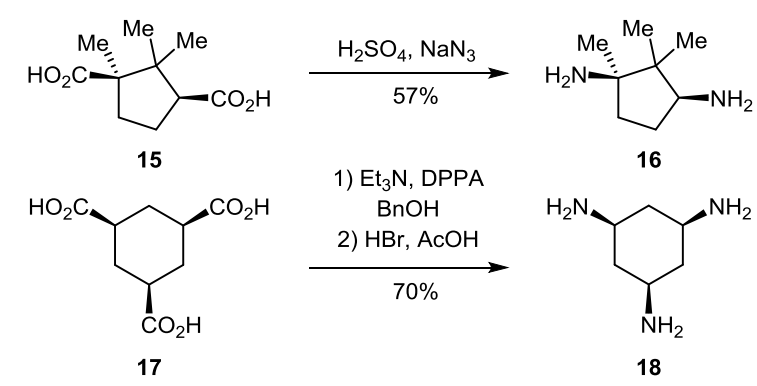

Scheme 3 Selected examples of oxime reductions and Curtius Rearrangements.

Six-membered cyclic cis-1,3-diamines can finally be prepared starting from di-nitrobenzenes simply by converting the two $\mathrm{NO}_{2}$ groups into the corresponding amine functions and concomitantly dearomatizing the aromatic group to form a fully saturated ring (Scheme 4). ${ }^{25}$ Quite harsh conditions are however required to perform the two reductions in a single synthetic step. Other nitrogen-containing aromatic compounds (e.g. imines or 1,3-benzenediamines) can be submitted to a reductive dearomatization as well.25a,33

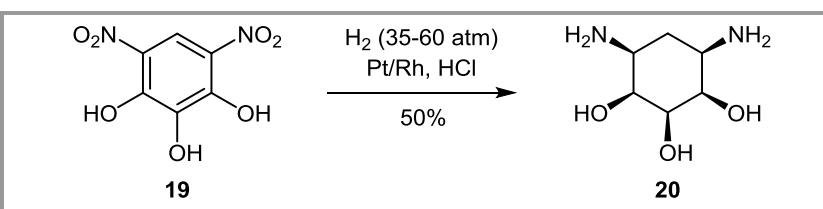

Scheme 4 Example of nitroarene reduction

All of these transformations generally proceed with low levels of stereocontrol. Mixtures of cis- and trans-1,3 diamines are 
therefore frequently obtained in moderate to good yields as main reaction products.

Taking the above mentioned examples into account, it appears clear that cyclic cis-1,3-diamines, and in particular fivemembered rings, can hardly be synthesized in a straightforward manner with high levels of relative or absolute stereocontrol. The development of new rapid and versatile processes leading to the stereoselective formation of this class of compounds therefore still remains an important challenge for synthetic organic chemists.

\section{4. $\quad \mathrm{N}-\mathrm{N}$ bond cleavage of bicyclic hydrazines: a versatile method to access cis-1,3-diamines}

A less common but intriguing approach to prepare cyclic cis1,3-diamines is based on the reductive cleavage of the $\mathrm{N}-\mathrm{N}$ bond in bicyclic systems containing an hydrazine subunit. These key compounds can easily be synthesized through a Diels-Alder cycloaddition starting from cyclopentadiene and using differently substituted diazo compounds as dienophile counterparts (Scheme 5).

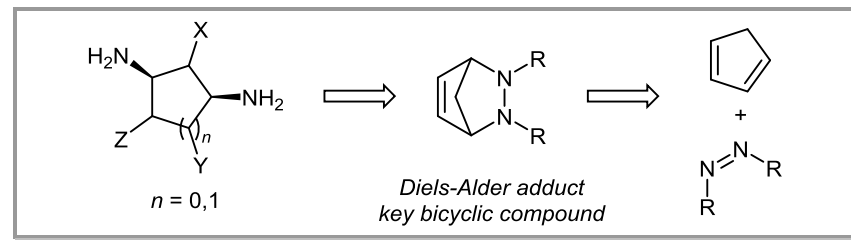

Scheme 5 Access to cyclic cis-1,3-diamines using Diels-Alder reactions and $\mathrm{N}-\mathrm{N}$ bond cleavages as key synthetic steps.

First reported in the eighties, ${ }^{34}$ this method allows the formation of the two C-N bonds in a single synthetic step with a total control of their relative (syn) configuration. By appropriate functionalization of key Diels-Alder cycloadducts, over the past few years, we have been able to adapt this procedure to the preparation of both five- and six-membered cyclic cis-1,3-diamines. In the next sections we will give an overview of the different scaffolds that were synthesized in our group using this convenient strategy.

\subsection{Preparation of five-membered cyclic cis-1,3- aminoalcohols}

Various five-membered cyclic cis-1,3-diaminoalcohols have been successfully synthesized in few steps starting from readily available compounds and using the nitrogen-nitrogen bond cleavage of hydrazines described above as a key reaction. A first series of compounds was prepared through the epoxidation of the bicyclic adduct 21a, easily obtained via a Diels-Alder cycloaddition between cyclopentadiene and dibenzyl azodicarboxylate (Scheme 6). ${ }^{35}$ The acid-catalyzed rearrangement of epoxide 22a, and subsequent nucleophilic attack, led to the formation of substituted bicyclic hydrazines 23a-d in a regio- and stereoselective manner (Scheme 6). ${ }^{36}$ Different reaction conditions were used to perform this transformation. Treatment of the epoxide 22a with sulfuric acid in a non-nucleophilic solvent (trifluoroethanol) allowed the functionalization of the bicyclic system with an additional hydroxyl group. A methoxy substituent was added onto the molecule under similar conditions when methanol was employed as the solvent. Lewis acid activated reactions in the presence of organoaluminum reagents led to the formation of new carbon-halogen or carbon-carbon bonds. All the observed skeletal rearrangements allowed the control of the relative configuration of four contiguous stereocenters in a single operation, and were supposed to proceed via the formation of an aziridinium intermediate. ${ }^{36}$ As a last synthetic step, hydrogenolysis over platinum oxide under acidic conditions of the hydrazine bond afforded the desired aminocyclopentanes 24a,b in almost quantitative yield (Scheme 6).

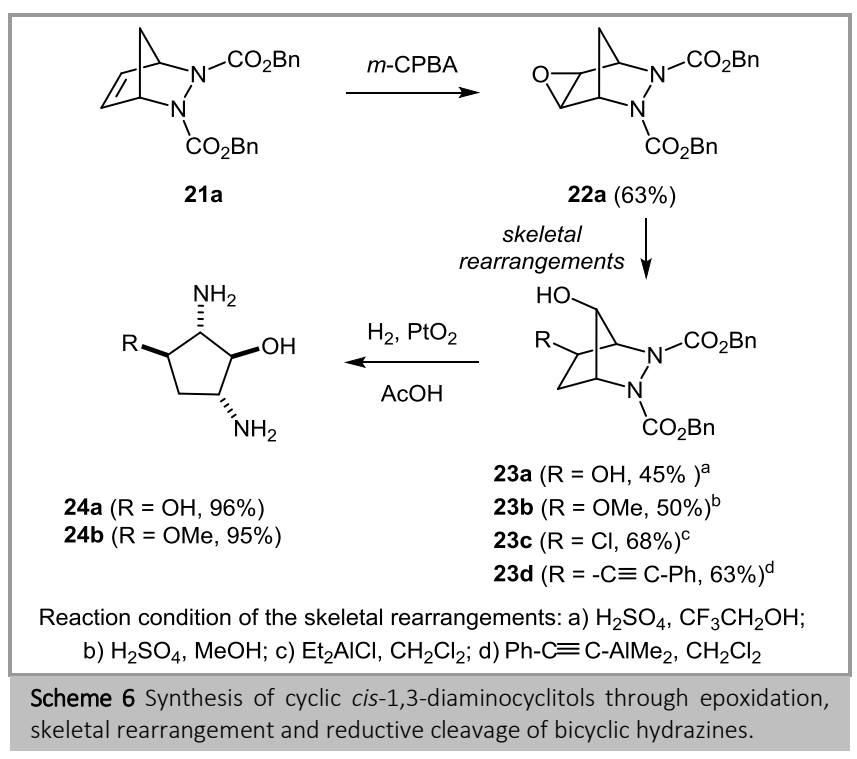

The hydroboration of different Diels-Alder adducts (21a-d Scheme 7) was also investigated with the aim to prepare a second series of cyclic cis-1,3-diaminoalcohols. Treatment of the bicyclic compounds with $\mathrm{BH}_{3} \bullet \mathrm{THF}$ followed by oxidative workup afforded the corresponding hydroxylated racemic products 25a-d in moderate to good yields (Scheme 7). A reductive cleavage of the hydrazine bond was then used as the key step to access hydroxylated $N$-protected cyclic cis-1,3diamines (Scheme 7). ${ }^{37}$

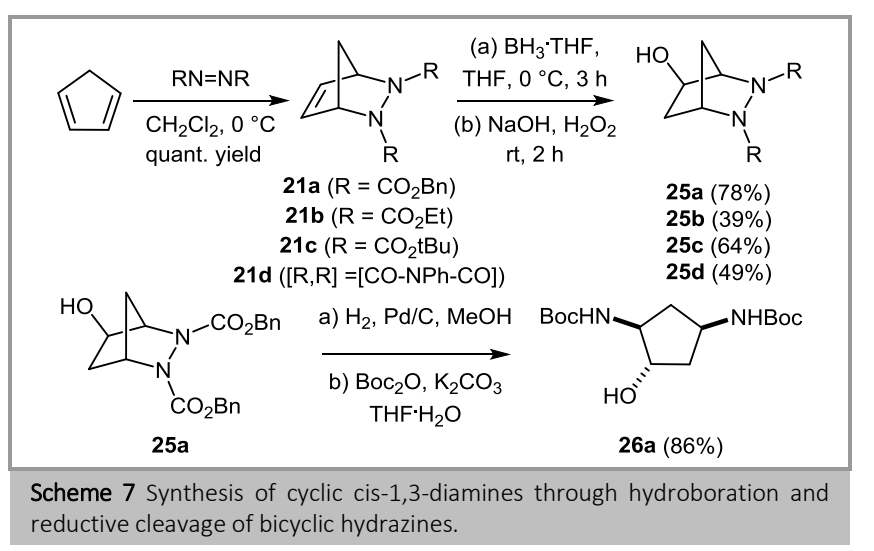

Asymmetric hydroborations were studied as well. In this case, a reversal of the enantioselectivity of the reaction was observed in the presence of chiral diphosphine ligands and Rhor Ir-based catalysts. ${ }^{37}$ Treatment of meso hydrazine 21a with catecholborane (CatBH), $[\mathrm{Rh}(\mathrm{COD}) \mathrm{Cl}]_{2}$, and $(\mathrm{S}, \mathrm{S})$-BDPP in DME afforded the corresponding hydroxylated product 25 a in $90 \%$ yield and $84 \% e e$. The absolute configuration of this compound $(1 R, 4 R, 5 R)$ was confirmed by X-ray analysis after reductive 
cleavage of the $\mathrm{N}-\mathrm{N}$ bond and subsequent protection of the final diamino alcohol as $p$-bromo dibenzamide (Scheme 8). ${ }^{37}$ Interestingly, when $[\operatorname{Ir}(\mathrm{COD}) \mathrm{Cl}]_{2}$ was employed as catalyst to promote the hydroboration, the hydroxylated derivative of opposite configuration $(1 S, 4 S, 5 S)$ was isolated as the major product (Scheme 8). Differently substituted meso hydrazines behave similarly under the same experimental conditions. ${ }^{37}$ In an effort to rationalize the reaction mechanism, two different insertion pathways were invoked to explain the systematic reversal of enantioselectivity observed with the two transition metal complexes. While the use of $[\mathrm{Rh}(\mathrm{COD}) \mathrm{Cl}]_{2}$ was supposed to involve a key Rh-H migratory insertion step, we suggested that a metal-boron insertion could be favored when using the $[\operatorname{Ir}(\mathrm{COD}) \mathrm{Cl}]_{2}$ catalyst. $^{37}$

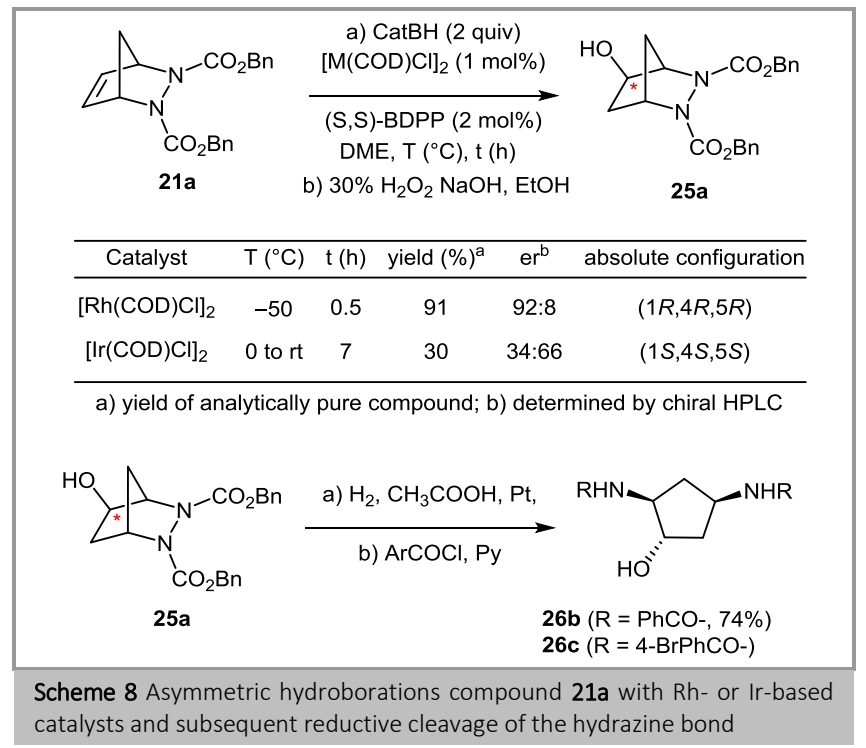

Chiral diphosphines also play an essential role in controlling the seterochemical outcome of the asymmetric hydroboration (Scheme 9).

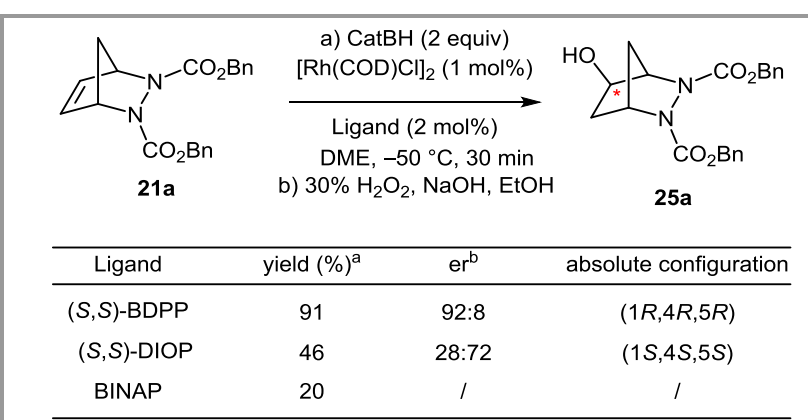

a) yield of analytically pure compound; b) determined by chiral HPLC

Scheme 9 Asymmetric hydroborations compound 21 a with $[\mathrm{Rh}(\mathrm{COD}) \mathrm{Cl}]_{2}$ in the presence of different diphosphine ligands.

Indeed, alcohols of opposite absolute configuration were obtained while promoting the reaction with $[\mathrm{Rh}(\mathrm{COD}) \mathrm{Cl}]_{2}$, simply by replacing the (S,S)-BDPP ligand with (S,S)-DIOP (Scheme 9). ${ }^{37}$ However, a racemic product was isolated in low yield in the presence of BINAP (Scheme 9).37a P,N-ligands could be used in place of diphosphines with the $[\operatorname{Ir}(\mathrm{COD}) \mathrm{Cl}]_{2}$ catalyst, and, in this case, the desired hydroxylated product 25a was isolated in a better yield and in a higher enantiomeric excess (Scheme 10). ${ }^{38}$

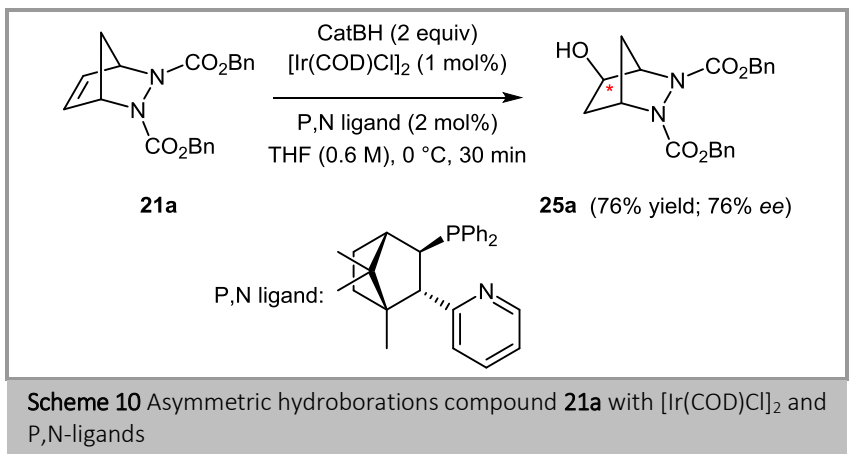

As confirmed by NMR analysis, the hydroboration of bicyclic hydrazines exclusively led to the formation of exo alcohols. ${ }^{37}$ The inaccessibility of the endo face, probably hindered by a pseudo axial carbamate, was confirmed by many unsuccessful trials of alcohol inversion by $\mathrm{S}_{\mathrm{N}} 2$ type mechanisms. To obtain an all-cis diamino alcohol, the enantioenriched hydroxylated hydrazine 25a was converted to the corresponding ketone by Swern oxidation (Scheme 11). Subsequent reduction of the carbonyl group, followed by $\mathrm{N}-\mathrm{N}$ bond cleavage and protection of the free amino groups as N-tert-butyl-carbamates led to the formation of the enantioenriched compound 29 in a good overall yield (Scheme 11). ${ }^{39}$

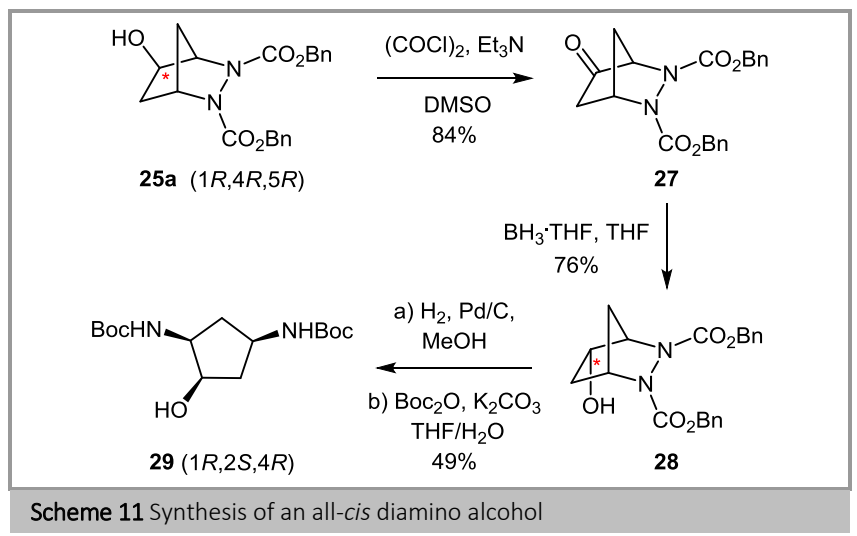

In order to prepare dihydroxylated products, bicyclic hydrazine 21a was finally engaged in a reaction with osmium tetroxide to afford hydrazine $\mathbf{3 0}$ in $90 \%$ yield (Scheme 12). The reductive cleavage of the $\mathrm{N}-\mathrm{N}$ bond of this compound successfully leaded to the formation of diaminodiol 31, which could be isolated in a quantitative yield (Scheme 12).

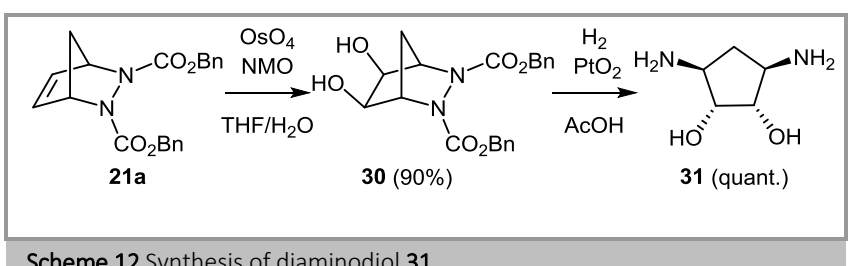

Scheme 12 Synthesis of diaminodiol 31 


\subsection{Access to fluorinated 1,3-cis- diaminocyclopentanes}

The introduction of a fluorine atom onto organic compounds can significantly influence their physicochemical properties and is nowadays considered as a classical strategy to tune their biological activities. ${ }^{40}$ In this context, we naturally became interested in the possibility to develop practical ways to prepare fluorine-containing cyclic cis-1,3-diamines in an enantio- and/or diastereoselective manner by using the reductive cleavage of hydrazine as a key step. One of the objectives was to tune the acidity of the amines in order to modify their affinity with RNA (see infra), another one was to use fluorinated diamines as tools for ${ }^{19} \mathrm{~F}$ NMR.

Fluorinated 1,3-cis-diaminocyclopentanes were successfully synthesized starting from racemic or enantioenriched hydroxylated bicyclic hydrazine 25a. ${ }^{39}$ Treatment of this compound with $\mathrm{N}, \mathrm{N}$-diethylaminosulfur trifluoride (DAST) led to the formation of the corresponding fluorinated bicycle $\mathbf{3 2}$, which was isolated as a single diastereomer (Scheme 13). The formation of a transient aziridinium was taken into account to explain the retention of the relative configuration observed after the reaction. The formation of this transient meso species was confirmed when a racemic product was isolated starting from the enantioenriched hydrazine ( $e e=84 \%$, Scheme 13 ). N$\mathrm{N}$ bond cleavage of hydrazine rac-32 ultimately afforded the racemic fluorinated cis-1,3-diamine $\mathbf{3 3}$ in $\mathbf{8 0} \%$ yield (Scheme 13).<smiles>O=C(OCc1ccccc1)N1C2CC(O)CC1C2</smiles>

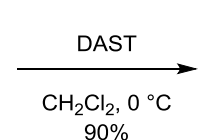
$90 \%$

25a $($ racemic or ee $=84 \%$ )

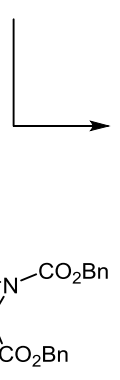

32

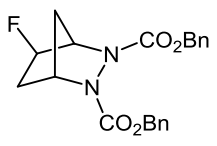

32 (racemic)
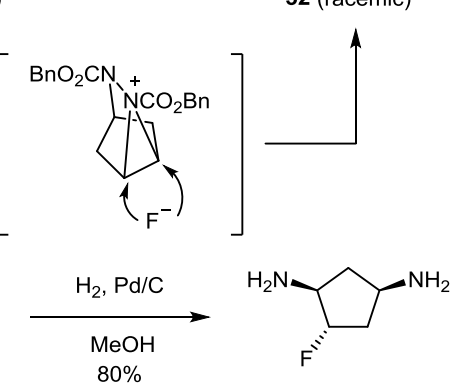

33
Scheme 13 Fluorination of bicyclic hydrazine 25a

With the aim to avoid the racemisation process and to isolate enantioenriched product (-)-33, the all-cis Boc protected amino-alcohol 29 (non-racemic compound with a $1 R, 2 S, 4 R$ absolute configuration) was next submitted to the fluorination reaction with DAST. This step proceeded with a complete inversion of the configuration at the carbon atom bearing the leaving group, ${ }^{39}$ any anchimeric participation of the nitrogen protecting group being precluded by the cis relationship existing between the $-\mathrm{OH}$ and -NHBoc functions (Scheme 14).

An alternative synthetic pathway was envisaged to access an all-cis enantioenriched fluorinated compound. The hydroxylated bicyclic hydrazine $\mathbf{2 5 a}$ was reductively cleaved and the two amines were protected with four different protective groups (Scheme 15).

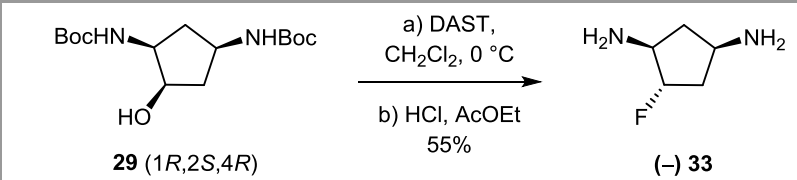

Scheme 14 Synthesis of enantioenriched fluorinated 1,3-cisdiaminocyclopentane (-)-33.

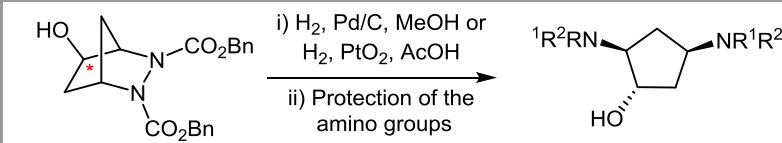

25a

a) $\mathrm{Boc}_{2} \mathrm{O}, \mathrm{K}_{2} \mathrm{CO}_{3}, \mathrm{THF} / \mathrm{H}_{2} \mathrm{O}$; b) $\mathrm{TsCl}$, $\mathrm{CH}_{2} \mathrm{Cl}_{2} / \mathrm{NaOH}(1 \mathrm{M}) ;$ c) $\mathrm{BnBr}, \mathrm{K}_{2} \mathrm{CO}_{3}$, $\mathrm{H}_{2} \mathrm{O} /$ Acetone; d) DNFB, $\mathrm{Et}_{3} \mathrm{~N}, \mathrm{THF}$

26a $\left(R^{1}=H ; R^{2}=\text { Boc, } 86 \%\right)^{a}$ 26d $\left(R^{1}=\mathrm{H} ; \mathrm{R}^{2}=\mathrm{Ts}, 57 \%\right)^{\mathrm{b}}$ 26e $\left(R^{1}, R^{2}=B n, 80 \%\right)^{c}$ $26 f\left(R^{1}=H ; R^{2}=D N P, 81 \%\right)^{d}$
Scheme 15 Synthesis of protected diaminoalcohols $26 a, d-f$

The fluorination of these derivatives was then studied. The nature of the protective groups on the nitrogen atoms was found to significantly influence the outcome of this transformation. Indeed, Boc and tosyl groups actively participated to the reaction, leading to the formation of oxazolidinone $\mathbf{3 4}$ and meso aziridine $\mathbf{3 6}$ as the major products (Scheme 16). On the contrary, tetrabenzyl derivative $26 \mathrm{e}$ was converted into the corresponding racemic trans fluorinated compound $\mathbf{3 8}$ through a transient meso aziridinium intermediate (Scheme 16). Only 2,4-dinitrophenyl (DNP) groups allowed the fluorination reaction to proceed with full inversion of configuration at the stereocenter bearing the leaving group. The enantioenriched compound $\mathbf{3 9}$ could be obtained in this case, albeit in a low 21\% yield (Scheme 16).

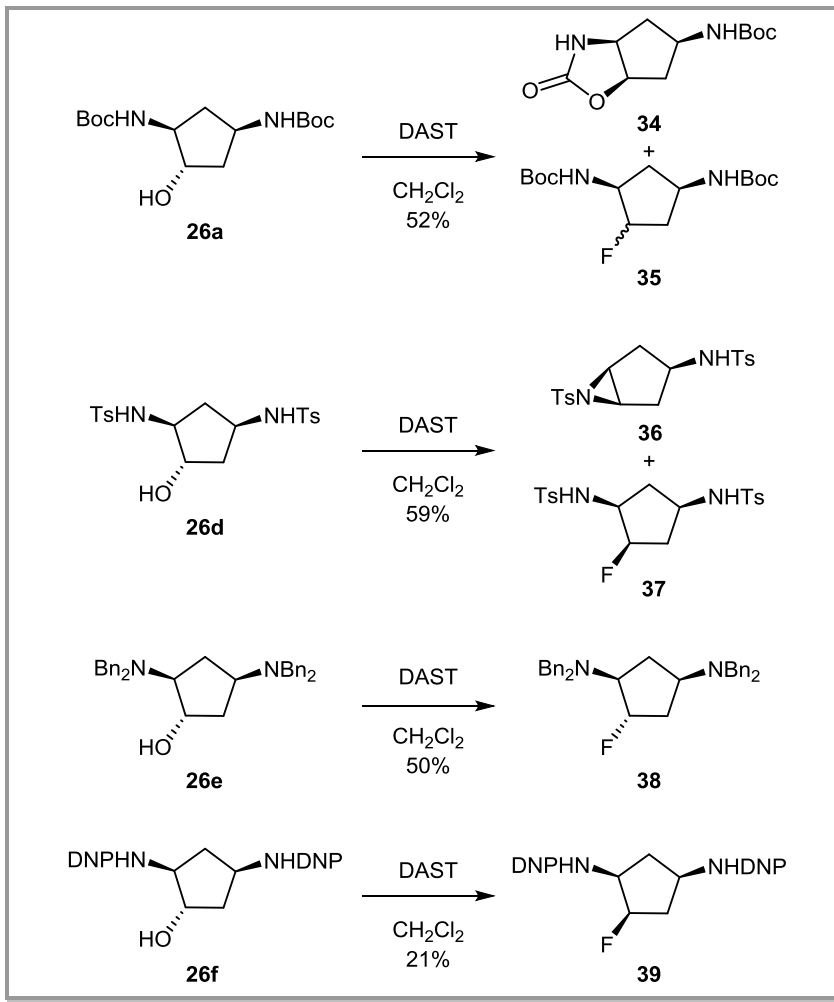

Scheme 16 Fluorination reactions of differently-protected cyclic diamino compounds. 
A sequence of deprotection/protection/deprotection was lastly required to isolate the pure fluorinated diamino compound $\mathbf{4 0}$ (hydrochloride form) starting from compound 39 (Scheme 17). 39

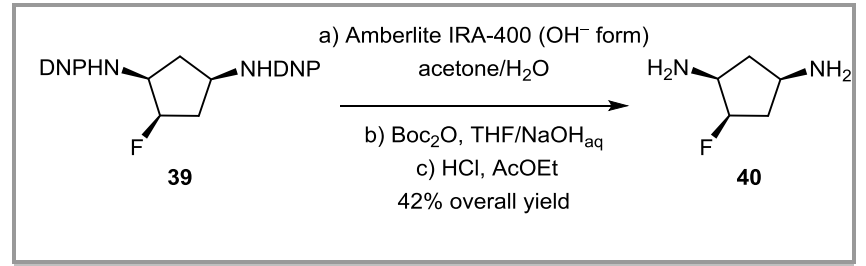

Scheme 17 Access to pure fluorinated free amino compound 40

Fluorinated cyclic cis-1,3-diamines bearing a hydroxyl group at different positions can also be prepared starting from the bicyclic hydrazines. ${ }^{39}$ A 1,2,3,4-tetrasubstituted cyclopentane could indeed be synthesized via the dihydroxylation of compound 21a, followed by a reductive cleavage of its hydrazine moiety and subsequent protection of the resulting free amines with DNP groups (Scheme 18). 0-monobenzylation of diol 41, and consequent reaction with DAST delivered the protected fluorinated tetrasubstituted cyclopentane $\mathbf{4 2}$ as a single diastereomer (Scheme 18). A final sequence of deprotection/protection/deprotection reactions enabled to obtain product $\mathbf{4 3}$ in its hydrochloride form (Scheme 18).

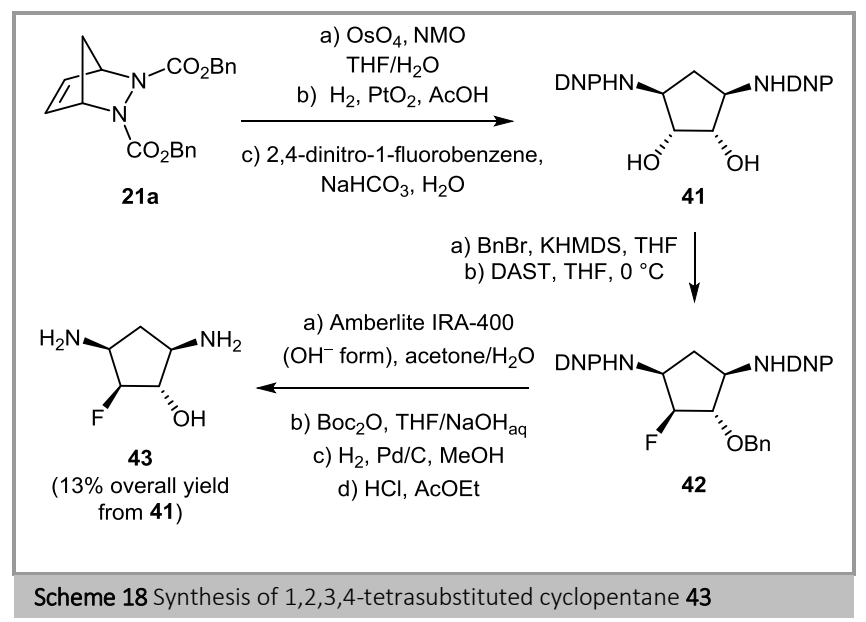

A 1,2,4,5-tetrasubstituted cyclopentane was finally obtained starting from bicycic hydrazine 23a. This compound was prepared via the epoxidation of derivative 21a and subsequent skeletal rearrangement as described in section 4.1 (Scheme 6). The treatment of hydrazine 23a with DAST delivered product 44 in a chemo- and diastereoselective manner. To explain the remarkable selectivity of the fluorination reaction, a mechanism involving the activation of both hydroxyl groups was postulated. The restricted conformational freedom of the carbamates caused by the presence of the hydroxymethylene group was supposed to force the nitrogen lone pairs of the hydrazine to be either in a pseudo equatorial or in a pseudo endo axial position (intermediate A, Scheme 19). Stereoelectronic effects were therefore assumed to favor the departure of the leaving group located on the ethylene bridge. Steric hindrance generated by the second activated hydroxyl group (intermediate B, Scheme 19) was finally invoked to account for the excellent regioselectivity of the final ring- opening step (Scheme 19). Control experiments were realized to support the proposed mechanism. ${ }^{39}$

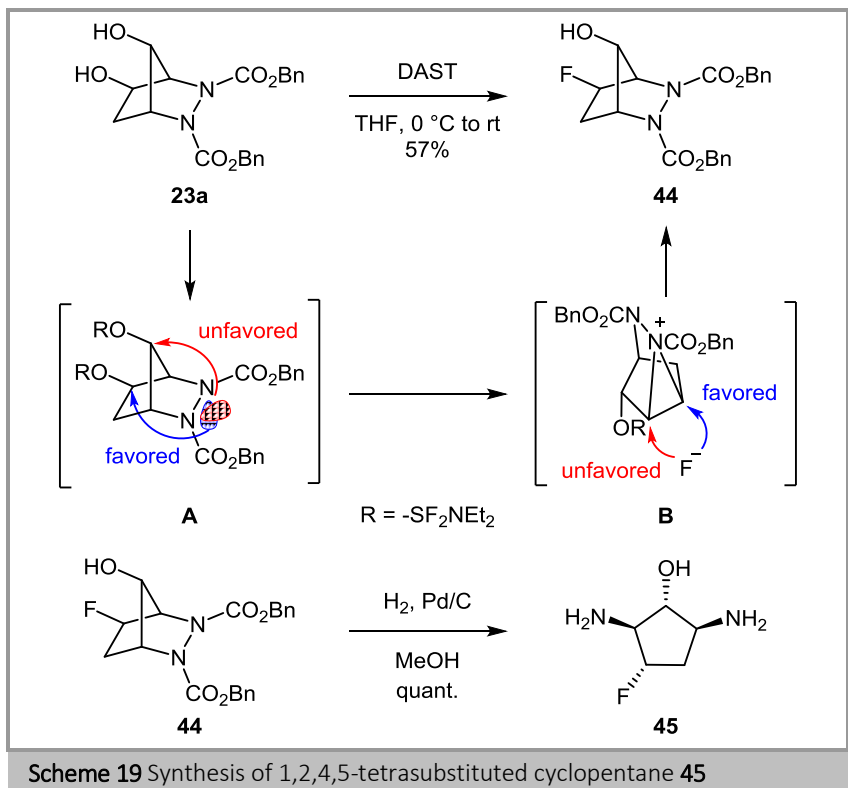

In the last synthetic step, compound $\mathbf{4 4}$ was successfully submitted to hydrogenolysis to isolate fluorinated cyclic cis1,3-diamine 45 in quantitative yield (Scheme 19).

\subsection{Synthesis of cis-1,3-diaminocyclohexitols}

The synthetic potential of diazabicyclo[2.2.1] heptane scaffold is not limited to the synthesis of 5 -membered rings. It is indeed possible to access to 6-membered rings by a one atom homologation playing with the reactivity of the double bond. Recently, the versatile reactivity of hydrazine 21a has been exploited in our laboratory to access various cis-1,3diaminocyclohexitols. ${ }^{41}$ Bicyclic compound 21a was either submitted to ozonolysis or engaged in a two-step dihydroxylation-oxidative cleavage sequence to form meso dialdehyde 46 in a straightforward fashion (Scheme 20). The cyclization of this derivative by treatment with nitromethane was then investigated. Different conditions were screened to perform the double nitroaldol condensation. No reaction was observed in the presence of $\mathrm{NaOH}$ (Scheme 20). The desired product $\mathbf{4 7}$ could be formed in low yield when using sodium alkoxide (Scheme 20). In this case, the basic conditions were supposed to promote a cleavage of the benzylcarbamates, as traces of benzyl alcohol were detected by ${ }^{1} \mathrm{H}$ NMR of the crude reaction mixture. Compound $\mathbf{4 7}$ was finally obtained in a high yield when running the reaction with trimethylamine, ${ }^{41}$ and using nitromethane as the solvent. Interestingly, cyclic product 47 was formed as a single diastereomer, although six possible isomers could theoretically be obtained through the condensation. The ring-homologation of bicyclic hydrazine 21a thus enabled to control the relative configuration of five contiguous stereogenic centers in a single operation. The relative configuration of derivative $\mathbf{4 7}$ was determined through NMR studies $\left({ }^{1} \mathrm{H}\right.$ and ${ }^{13} \mathrm{C}$ experiments, correlation and NOE spectroscopy). ${ }^{41}$ To explain the observed selectivity, dialdehyde 46 was supposed to react by keeping a Cs symmetrical conformation, and the cyclisation was thought to proceed under thermodynamic control. 


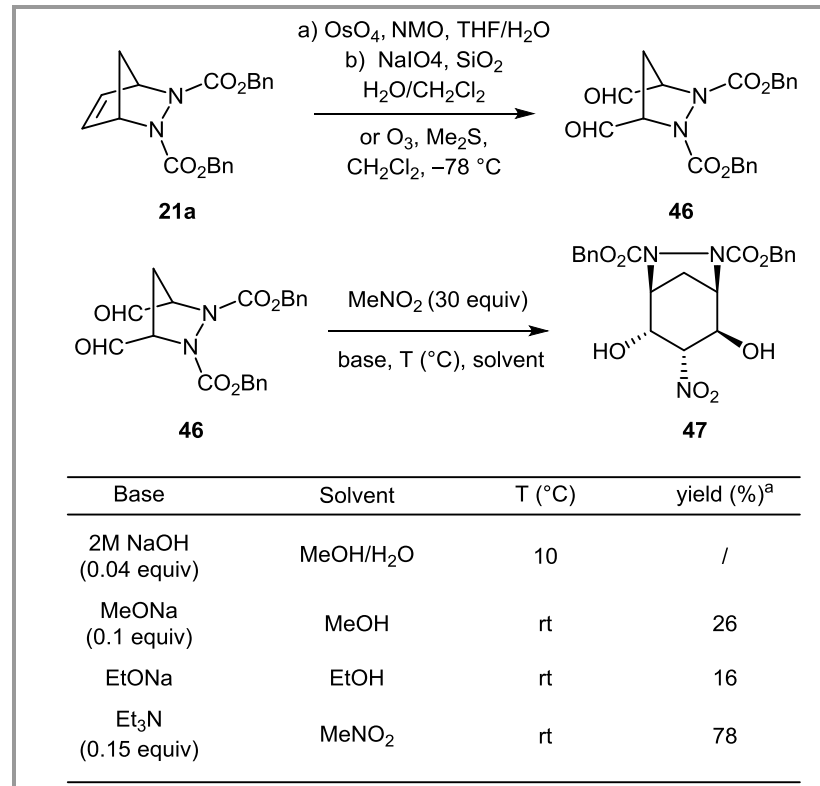

a) overall yield from compound 21a

Scheme 20 Nitroaldol condensation reactions

Hydrogenolysis under acidic conditions led to the full reduction of bicycle $\mathbf{4 7}$, and delivered cis-1,3diaminocyclohexitol $\mathbf{4 8}$ in a quantitative yield (Scheme 21). The nitro function of derivative $\mathbf{4 7}$ could also be reduced in a selective manner by treatment with zinc in acetic acid (Scheme 21). Reductive aminations with aldehydes or ketones could be used to functionalize product 49. The N-N hydrazine bond of the resulting bicycles was finally cleaved to obtain $\mathrm{N}$ substituted triaminocyclohexitols $\mathbf{5 0 a}, \mathbf{b}$ in a good overall yield (Scheme 21).

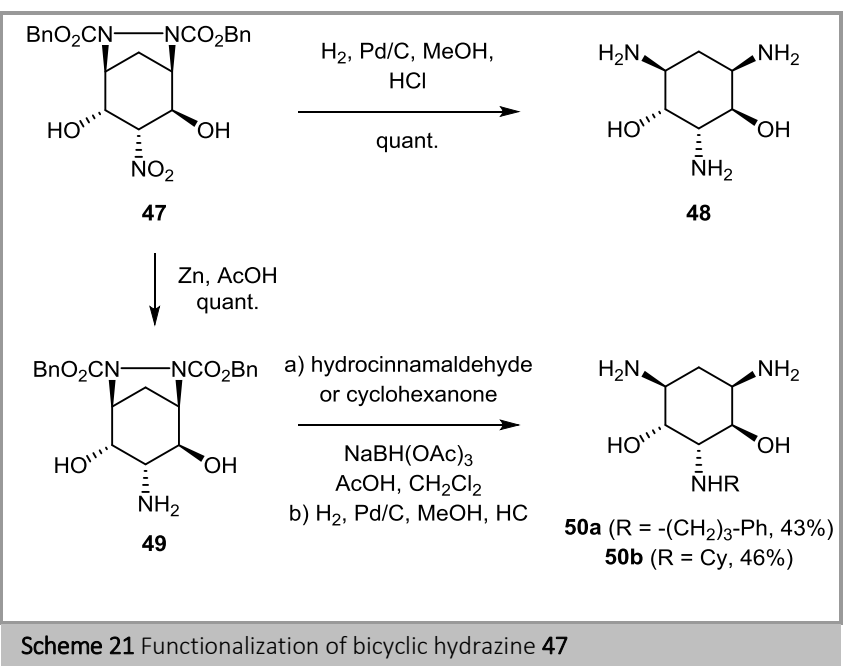

Acid-catalyzed skeletal rearrangements were also investigated starting from hydrazine 47.41 Despite our many efforts, the expected hydroxylated product could never been obtained. However, a brominated adduct was isolated when the reaction was conducted in the presence of a bromine source (Scheme 22). The formation of a transient azetidinium followed by a selective ring opening was proposed to explain the formation of the rearranged product 51. Hydrogenolysis of this derivative finally afforded diamine $\mathbf{5 2}$ in a quantitative yield as its hydrochloride salt (Scheme 22).

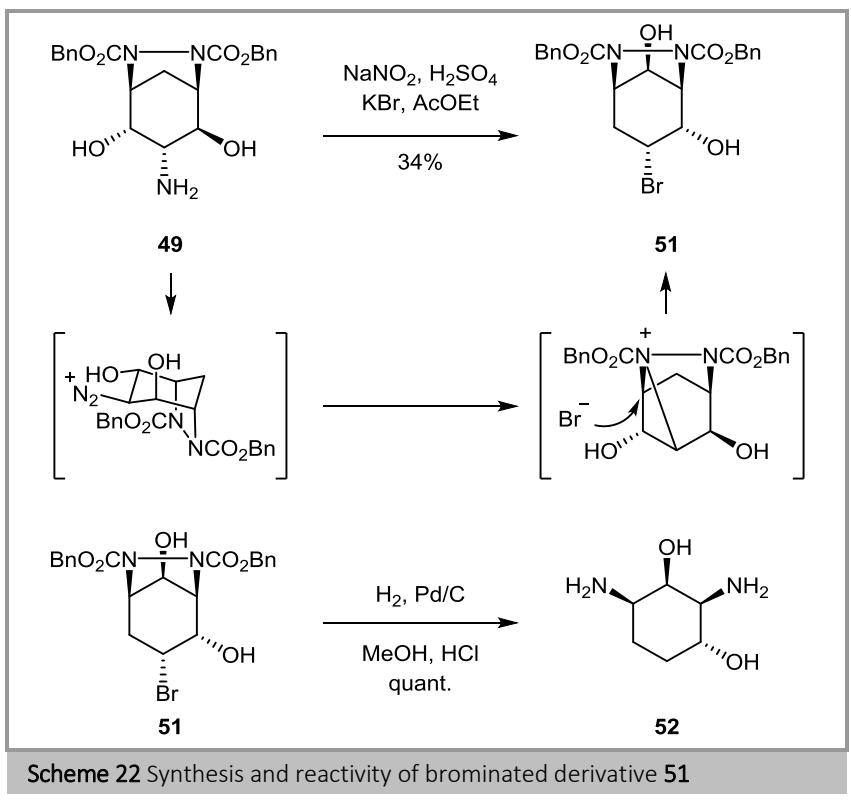

\subsection{Formation of cyclic cis-3,5-diamino-piperidines}

Meso cis-3,5-diaminopiperidines can be considered as valuable building blocks for the preparation of 2-deoxystreptamine (DOS) analogues since libraries of compounds can rapidly be prepared simply by functionalizing the piperidine nitrogen atom as reported by Hermann and co-workers (Scheme 23). ${ }^{42}$

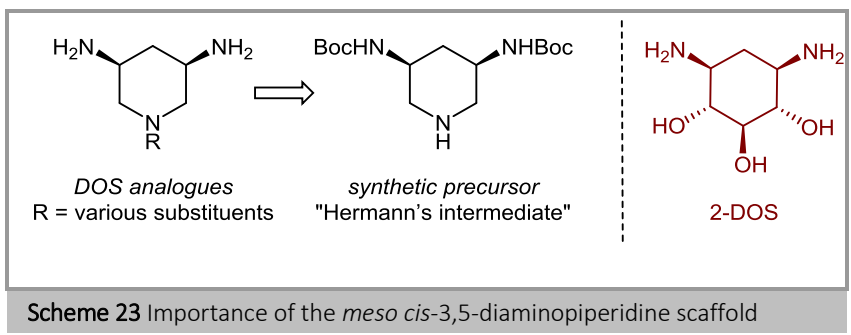

However, previously reported syntheses of this class of compounds rely on tedious high-pressure hydrogenation steps. In addition, the selective derivatization of the piperidine nitrogen atom in the presence of cis-3,5-diamino groups also revealed to be problematic under certain experimental conditions. In our ongoing work on the preparation of cyclic cis-1,3 diamines, we considered the possibility overcome these synthetic limitations by exploiting the reactivity of bicyclic hydrazines to develop a new general approach to access $\mathrm{N}$ substituted cis-3,5-diaminopiperidines.

Starting from hydrazine 21a, dihydroxylation and oxidative cleavage (or alternatively ozonolysis) were again preformed to prepare the relatively unstable key dialdehyde 46. This compound was then directly submitted to a series of double reductive amination reactions in the presence of various amine derivatives (Scheme 24). ${ }^{43}$ Aliphatic or aromatic amines readily reacted in the presence of $\mathrm{NaBH}(\mathrm{OAc})_{3}$ under acidic reaction conditions. Diamines could also be engaged in this transformation. Remarkably, this method allowed the introduction of a stereocenter $\alpha$ to the piperidine nitrogen without racemization. ${ }^{43}$ 


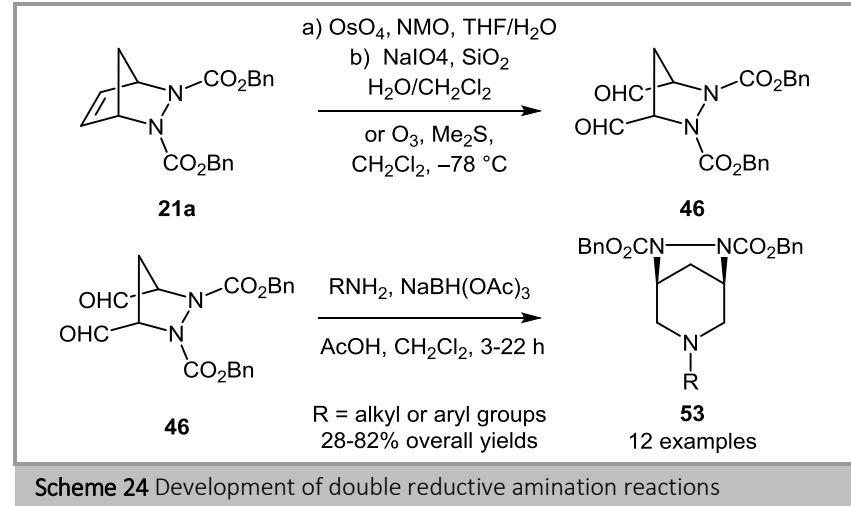

With the aim to access acylated triazabicyclo[3,2,1]octanes, product 53a, showing an allylic substituent at the piperidine nitrogen atom, was treated with palladiumtetrakis(triphenylphosphine) to form a NH-free bicyclic heterocycle (54, Scheme 25). This compound smoothly underwent acylation, peptidic coupling, or carbamoylation to afford the corresponding $\mathrm{N}$-acylated products 55a,b, 56 and 57 in high yields (Scheme 25).

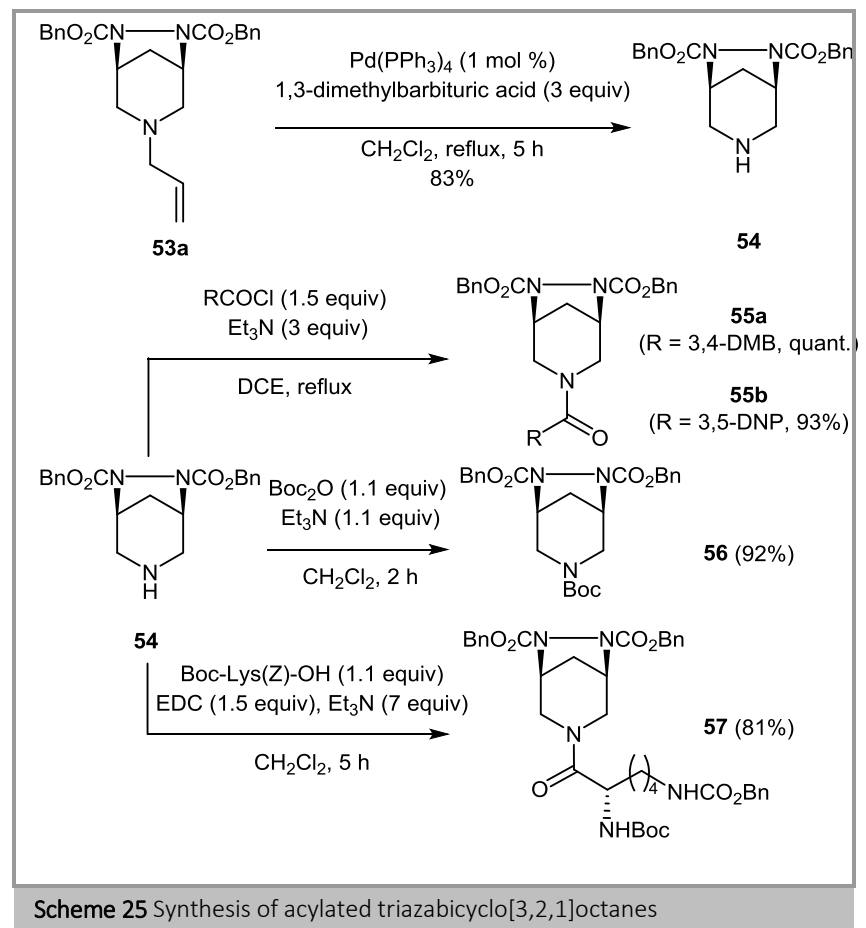

Differently functionalized bicyclic hydrazines 53, 55, and 56 were successfully submitted to hydrogenolysis in the presence of Pd- or Pt-based catalysts to generate the final cis-3,5diaminopiperidines 58a,f and 59a,b in good to quantitative yields (Scheme 26). In most cases, the reaction conditions had to be tuned in order to avoid catalyst poisoning or to prevent over-reduction of the (hetero)aromatic rings that frequently decorate the synthesized molecules.

Our strategy could finally be used to prepare Hermann's intermediate, ${ }^{43}$ without any high pressure reduction step (Scheme 27). The free $\mathrm{NH}_{2}$ - groups of product 58a were indeed easily protected by treatment with $\mathrm{Boc}_{2} \mathrm{O}$. The resulting derivative $\mathbf{6 0}$ reacted with CAN in the last step of the synthetic sequence to yield the desired Boc-protected cis-3,5diaminopiperidine in $58 \%$ yield $(44 \%$ overall yield from cyclopentadiene, Scheme 27).

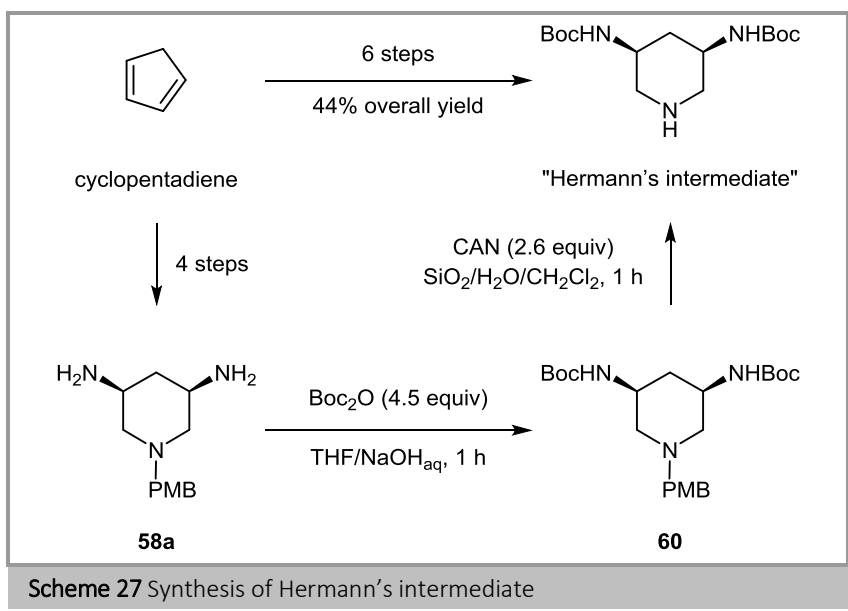

\section{Applications of cyclic cis-1,3-diamines}

All the synthetic transformations of bicyclic hydrazines described above enable a large coverage of chemical space around the cyclic 1,3 diamine motif. As briefly explained in section 2, this motif can be found in several classes of compounds possessing interesting biological properties. Among them, we focused our attention on aminoglycosides. The cyclic cis-1,3 diamines synthesized in our laboratory are structural mimetics of 2-deoxystreptamine (DOS), the central core of aminoglycosides. These natural products can be viewed as valuable "RNA friendly" molecules. 


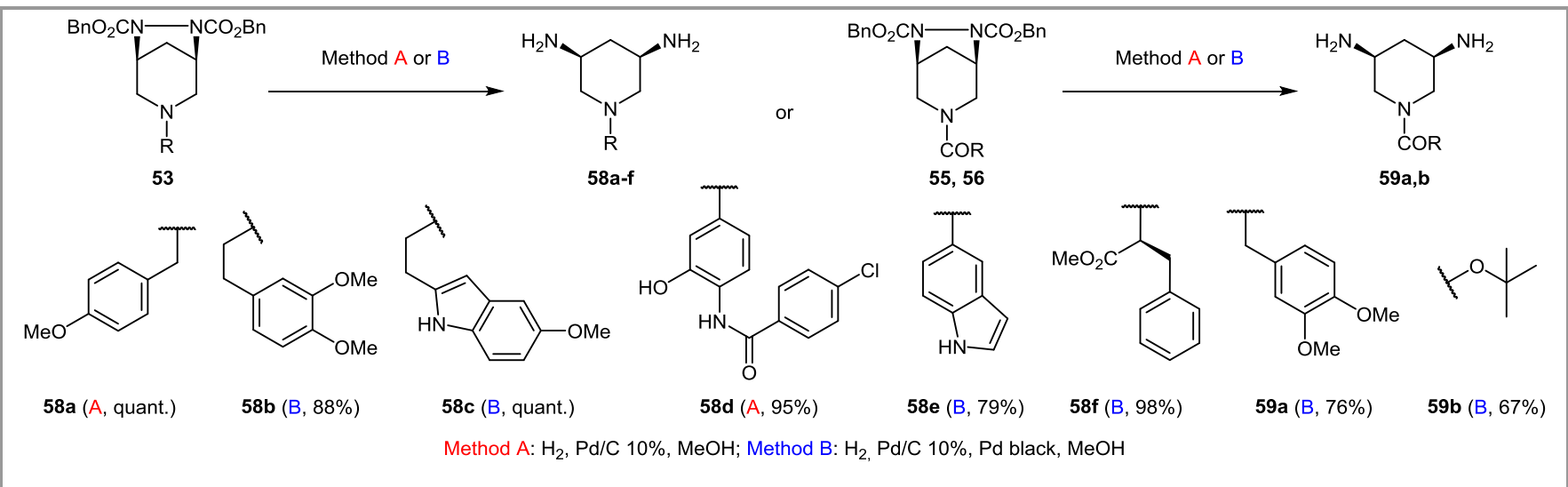

Scheme 26 Examples of hydrogenolysis of hydrazines 53,55 and 56 .

RNA is an essential biomolecule which is involved in the regulation of many cell processes. ${ }^{44}$ As a result, RNA is nowadays considered as an attractive target in drug discovery. ${ }^{45}$ In this context, the development of small molecules capable of binding specific RNA structures represent a major challenge for organic chemists. We therefore decided to explore the possibility to use our compounds as building blocks for the design of new RNA ligands and probes.

\subsection{Small molecular RNA binders}

Functional sites within the genomic RNA of HIV-1 have emerged as promising targets for new antiviral approaches. ${ }^{46}$ tRNA ${ }^{\text {Lys3 } 3}$ is the natural primer of HIV-1. In virions, tRNA ${ }^{\text {Lys3 }}$ interacts with the genomic RNA and forms a complex that recruits the reverse transcriptase, the enzyme responsible for viral replication.

We become interested in identifying small compounds capable of interacting with tRNA Lys3 in order inhibit the reversetranscription initiation complex. ${ }^{47}$ However, the rational design of selective binders of tRNA ${ }^{\text {Lys3 }}$ is a difficult task since its shape is very similar to that of other RNA molecules. This is reflected in the fact that only low-affinity structure-specific peptide ligands could be identified by following a combinatorial approach. 48

Taking advantage of well-known crystallographic ${ }^{49}$ and NMR data, ${ }^{50}$ our group undertook a fragment based approach ${ }^{51}$ to access new ligands of tRNA ${ }^{\text {Lys3 }}$. A NMR spectroscopic screening was performed with a focused library of organic compounds (prepared in-house or commercially available).52 Binding of these compounds to the target induced detectable changes in the 1D NMR spectra of tRNA ${ }^{\text {Lys3 }}$ (imino region, $\delta=10-15 \mathrm{ppm}$ ), and allowed us to identify racemic cyclic cis-1,3-diamine $\mathbf{6 1}$ (DACP) and kynuramine (62) as new RNA ligands (Figure 6).

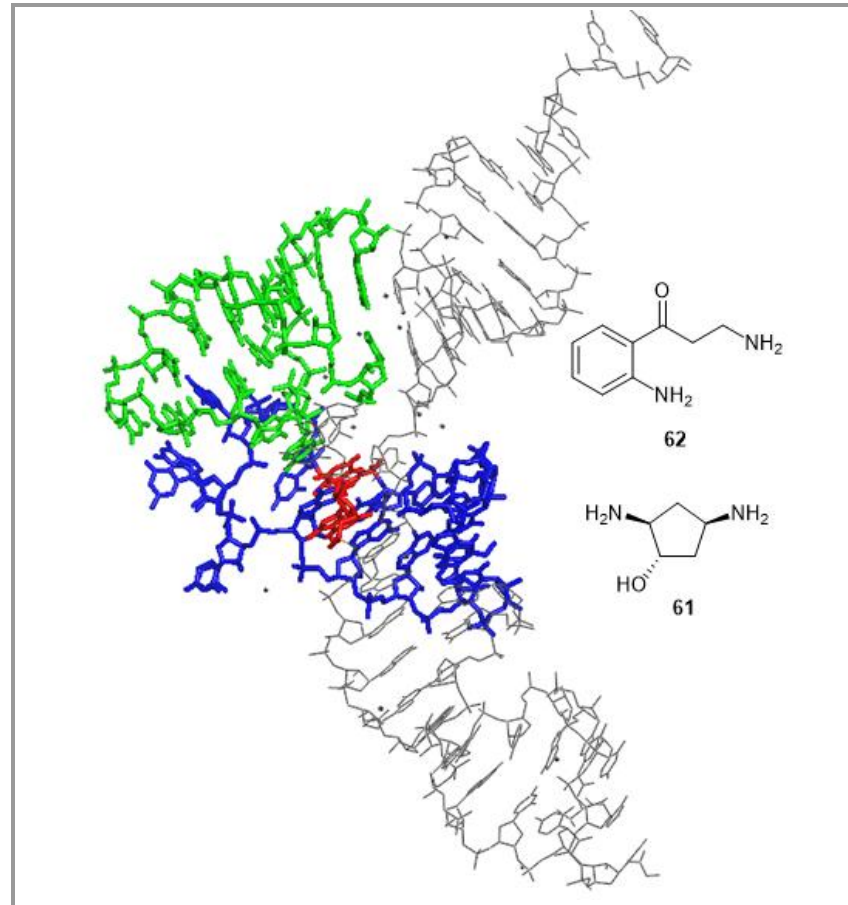

Figure 6 Mapping on tRNA ${ }^{\text {Lys } 3}$ structure (PDB code 1 FIR) of the binding zones of compound 61 (Blue, T-arm) and compound 62 (green, D-arm). G15 and $\mathrm{m} 7 \mathrm{G} 46$ are depicted in red.

2D HMQC experiments with ${ }^{15} \mathrm{~N}$-labeled tRNA allowed us to determine the NMR chemical shift mapping of the two ligands on tRNALys3. At least two binding sites were observed for compound $\mathbf{6 1}$ (one in the T-stem and the other near the D-arm, the binding to the $\mathrm{D}$ arm being observed at higher concentration of the ligand). On the contrary, derivative $\mathbf{6 2}$ was found to specifically interact with the D-stem (Figure 6). Two nucleotides (G15 and m7G46) resulted to be affected by the binding of both compounds (Figure 6). NMR titrations were employed to calculate the apparent dissociation constants of the new RNA ligands ( $2 \mathrm{mM}$ and $5 \mathrm{mM}$ respectively).

A qualitative specificity study was also realized by analyzing the NMR spectroscopic footprints of compounds $\mathbf{6 1}$ and $\mathbf{6 2}$ with other nucleotide sequences ( $\mathrm{tRNA}_{\mathrm{f}}{ }^{\mathrm{Met}}$ and $\mathrm{tRNAm}^{\mathrm{Met}}$ of $E$. coli). Interestingly, derivative $\mathbf{6 2}$ showed some sequence-specific binding. ${ }^{52}$ This result encouraged us to investigate the affinity between tRNA ${ }^{\text {Lys } 3}$ and various kynuramine analogues. Despite 
showing a close resemblance with the structure of derivative 62, commercially available compounds 63-68 (Figure 7) were not detected to bind to tRNA ${ }^{\text {Lys3 } 3}$ in chemical shift perturbations (CSP) experiments.

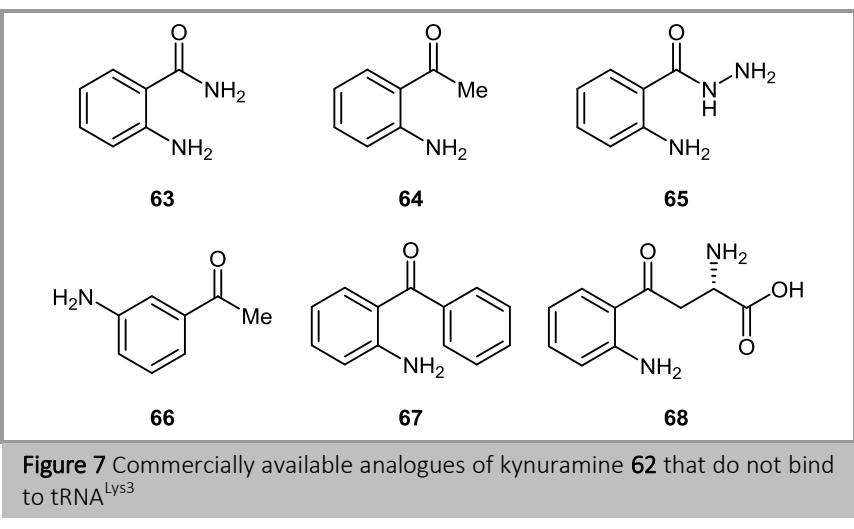

The covalent linkage of kynuramine-like fragments to diaminecontaining compound $\mathbf{6 1}$ was investigated next in order to improve the binding affinity of our RNA ligands. Short aminoester were first used as linkers with the aim to design Darm binders. ${ }^{52}$ Five representative linked products (73-77) were prepared in four steps starting from cyclic cis-1,3-diamine 26a (Scheme 28).

Under stoichiometric conditions, clear CPS was observed when comparing the NMR footprints of ligands $\mathbf{7 3 , 7 4}$ and $\mathbf{7 7}$ on the target tRNA ${ }^{\text {Lys3 } 3}$ and the 2D TROSY spectra of ${ }^{15} \mathrm{~N}$-labeled tRNA. ${ }^{52}$ The new binders also showed a reinforced selectivity for the Darm of tRNA ${ }^{\text {Lys3 } 3}$, although interactions with the T-stem were observed at higher RNA:ligand ratios. The dissociation constant of derivative $\mathbf{7 7}$ was estimated tacking advantage of its florescence properties, and a value in the micromolar range could be determined $\left(\mathrm{K}_{d}=8 \mu \mathrm{M}\right)$. The considerably improved affinity and reinforced selectivity of ligand $\mathbf{7 7}$ in comparison with those of fragments $\mathbf{6 1}$ and $\mathbf{6 2}$ clearly demonstrated the validity of the fragment based approach for the design of new RNA binders. However, ligands 73-77 proved to have a relatively low stability as their linker arms could undergo retroMichael reactions.

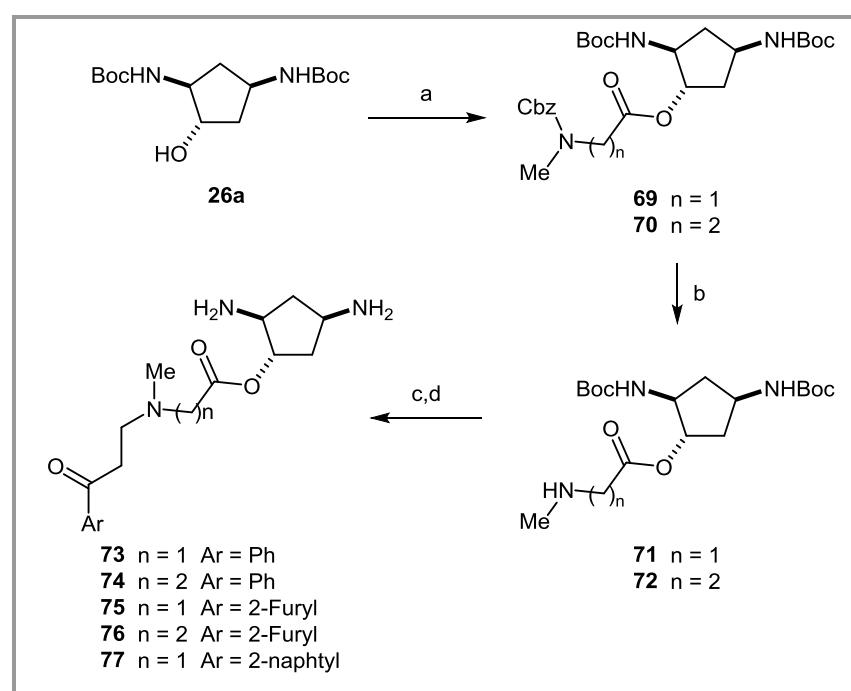

Reaction conditions: a) DCC, DMAP, $\mathrm{Cbz}(\mathrm{Me}) \mathrm{N}\left(\mathrm{CH}_{2}\right)_{\mathrm{n}} \mathrm{CO}_{2} \mathrm{H}, \mathrm{CH}_{2} \mathrm{Cl}_{2}, 16 \mathrm{~h}, 72$ $88 \%$; b) $\mathrm{H}_{2}$, $\mathrm{Pd} / \mathrm{C}$, AcOEt, 92-96\%; c) $\mathrm{ArCOCH}=\mathrm{CH}_{2}, \mathrm{CH}_{2} \mathrm{Cl}_{2}, 18 \mathrm{~h}, 26-84 \%$; d) $\mathrm{HClg}, \mathrm{AcOEt}$, quant.

Scheme 28 Connection of kynuramine-like fragments and cyclic cis-1,3diamine compounds with short aminoester linkers.

The linkage strategy was reinvestigated with $3+2$ cycloaddition reaction for connecting the fragments through a 1,4-triazole motif. A second series of RNA binders (81a-h) was synthesized in a straightforward manner using a practical one-pot procedure (Scheme 29). These compounds were isolated in 6\% to $66 \%$ overall yield after catch-and release purification on sulfonic acid resin. ${ }^{52}$ Binding of ligands 81a-h to tRNA ${ }^{\text {Lys3 }}$ was monitored by using TROSY NMR spectroscopy. Improved affinity and reinforced selectivity for the D-arm was again observed. Fluorescence binding assays revealed that the use of a 1,4-triazole-based linker afforded better RNA binders, as compounds 81a, 81c and 81f showed enhanced affinity and selectivity when compared to derivative $\mathbf{7 7}$ (Table 1).<smiles>C#CCO[C@H]1CC(NC(=O)OCc2ccccc2)CC1NC(=O)OCc1ccccc1</smiles>

Reaction conditions: a) $\mathrm{NaN}_{3}, \mathrm{H}_{2} \mathrm{O} /$ Acetone; b) $\mathrm{CuSO}_{4}$, sodium ascorbate; c) $\mathrm{HCl}, \mathrm{MeOH}$ then amberlyst resin, then $\mathrm{NH}_{3}, \mathrm{MeOH}$

Scheme 29 Connection of kynuramine-like fragments and cyclic cis-1,3diamine compounds with $3+2$ cycloaddition reactions 
The stereospecificity of the binding was also evaluated by studying the interaction of tRNA ${ }^{\text {Lys3 }}$ with the two enantiomers of compound 81f. Both racemic or enantiomerically pure compounds $\mathbf{8 1 f}$ binds to the same region of tRNA with similar strength (Table 1).

Table 1 Comparison of binding affinities of fragments 61,62 and RNA ligands $77,81 a, 81 c, 81$

\begin{tabular}{|c|c|c|c|c|}
\hline Entry & Compound & $\mathrm{K}_{\mathrm{d}}(\mu \mathrm{M})$ & Method & Binding site \\
\hline 1 & 61 & 1000 & NMR & T arm, D arm \\
\hline 2 & 62 & 5000 & NMR & D arm \\
\hline 3 & 77 & 8 & Fluorescence & D arm, then T arm \\
\hline 4 & $81 \mathrm{a}$ & 6 & Fluorescence & D arm \\
\hline 5 & $81 \mathrm{c}$ & 1.2 & Fluorescence & D arm \\
\hline 6 & $81 \mathrm{f}$ & 1.8 & Fluorescence & D arm \\
\hline 7 & $(2 R)-81 \mathrm{f}$ & 1.2 & Fluorescence & D arm \\
\hline 8 & $(2 S)-81 \mathrm{f}$ & 1.1 & Fluorescence & D arm \\
\hline
\end{tabular}

To gain a deeper insight into the influence of the linker on the binding properties of our ligands, we envisioned the possibility to replace the 1,4-triazole moiety with its 1,5- isomer, and thus shortening the distance between the two fragments without modifying the chemical nature nor the size of the linking arm.

A ruthenium-catalyzed azide-alkyne cycloaddition reaction (RuAAC), ${ }^{53}$ was successfully used to synthesize the desired compounds starting form fragments $\mathbf{7 8}$ and $\mathbf{8 0}$ (Scheme 30). ${ }^{54}$

Fluorescence-quenching assays were employed to estimate the dissociation constants of ligands $\mathbf{8 2 a - g}$ to tRNA ${ }^{\text {Lys3 }}$. Altering the orientation of the two fragments was found to entail a modest increase of the $K_{d}$ values. ${ }^{52,54}$ However, selectivity was lost as NMR studies clearly showed that all ligands could bind to both the $\mathrm{T}$ and D stem of tRNA ${ }^{\mathrm{Lys} 3}$. 54

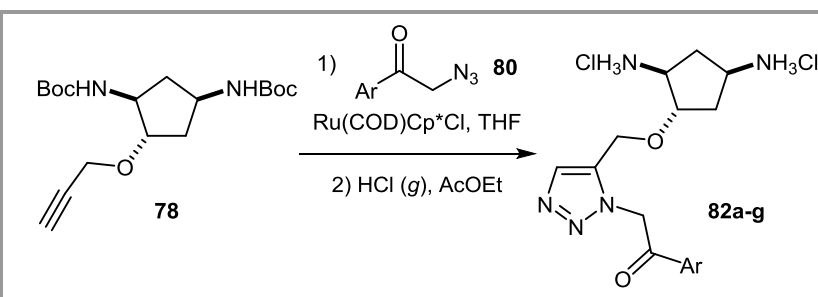<smiles>CCCC(=O)c1ccccc1</smiles>

82a $(80 \%)$<smiles>CCCC(=O)c1ccc2ccccc2c1</smiles>

82b $(66 \%)$<smiles>CC(C)CC(=O)c1ccc(-c2ccccc2)cc1</smiles>

82c $(63 \%)$

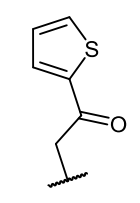

82d (51\%)

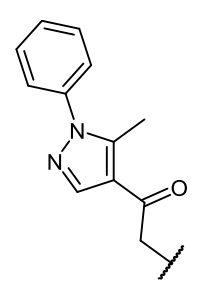

$82 \mathrm{e}(60 \%)$

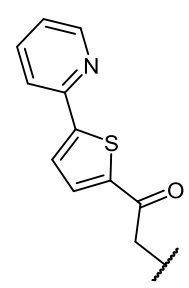

$82 f(44 \%)$

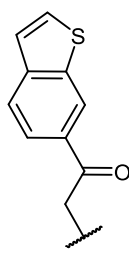

82g $(74 \%)$
Scheme 30 Connection of kynuramine-like fragments and cyclic cis-1,3diamine compounds with RuAAC reactions.
Interestingly, the binding interactions of ligand $\mathbf{8 2 b}$ with the $\mathrm{T}$ stem differed from those observed for compound $\mathbf{7 7}$. Since the interaction with the $\mathrm{T}$ stem was not detected in the presence of compound 81f, showing a 1,4 triazole moiety, ${ }^{54}$ we concluded that rigid linkers capable of imposing a long distance between the two fragments should prove essential in the design of site selective binders.

To confirm this assumption we finally synthesized a ligand incorporating a triazine linker, a good mimic of the 1,4-triazole motif (Scheme 31)..$^{54}$

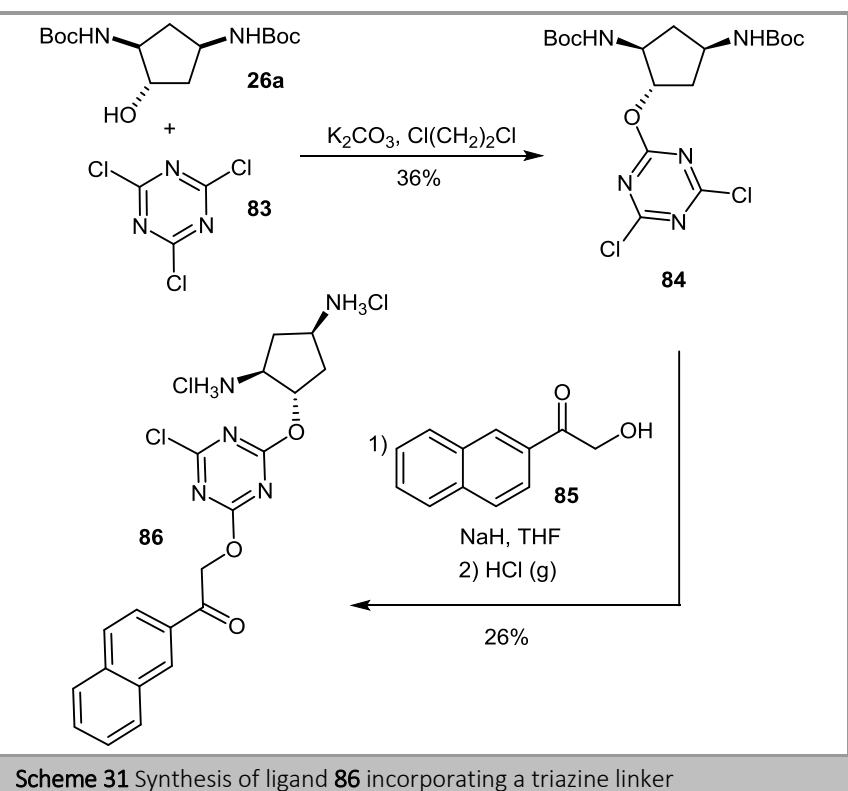

Cyclic cis-1,3-diamine 26a and $\alpha$-hydroxy-naphtylacetophenone 85 were chosen as aliphatic and aromatic fragments, and could be connected to cyanuric chloride $\mathbf{8 3}$ through successive substitution reactions (Scheme 31). As depicted by NMR TROSY experiments, the resulting triazine-containing ligand $\mathbf{8 6}$ proved to selectively interact with the $\mathrm{D}$ stem of tRNA ${ }^{\text {Lys3 }}\left(\mathrm{K}_{\mathrm{d}}=1.4\right.$ $\mu \mathrm{M}) .{ }^{54}$ This last result allowed as to unequivocally confirm that, together with the nature of the connected fragments, the linker characteristics play a key role in controlling the binding selectivity of our ligands and have to be taken into account when designing new RNA binders.

\subsection{Fluorinated 1,3 diamino cyclopentanes as NMR} probes

The use of cyclic 1,3 diamines as key components for the design of RNA binders being validated, we then explored the possibility to use fluorinated diaminocyclopentanes (Figure 9) as chiral sensitive NMR probes for studying RNA structures and dynamics as well as spy reporters in binding assays.

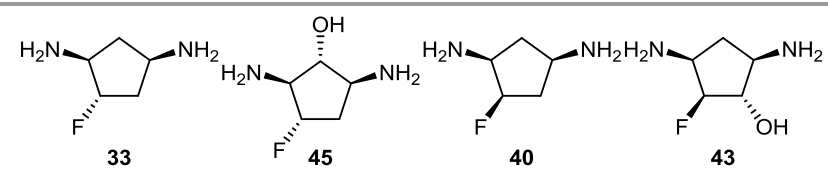

Figure 8 Fluorinated NMR probes 
${ }^{19} \mathrm{~F}$ NMR is indeed known to be very sensitive, and the fluorine shielding parameters are also known to strongly rely on local environment. The interaction of compound $\mathbf{3 3}$ (racemic or enantioenriched) with tRNA ${ }^{\text {Lys3 }}$ was investigated first by ${ }^{19} \mathrm{~F}$ NMR. Because compound $\mathbf{3 3}$ is only a millimolar RNA binder, the exchange between the free and bound forms was confirmed to be in the fast regime on the NMR timescale. Thus, each enantiomer led to a single ${ }^{19} \mathrm{~F}$ NMR signal. However, although the two enantiomers bind to tRNA ${ }^{\text {Lys3 }}$ with the same dissociation constant (around $1 \mathrm{mM}$ ), and on the same binding site, 55 they form diastereomeric complexes with the chiral RNA. As a consequence, two different averaged resonance shifts of the ${ }^{19} \mathrm{~F}$ NMR signal could be detected for each enantiomer of derivative 33 in the presence of tRNA ${ }^{\text {Lys3 }}$. The use of racemic derivative 33 led to a complete NMR resolution with a split of $0.5 \mathrm{ppm}$ (Figure 9). The interaction of racemic compounds 45,40 and 43 (Figure 8) with tRNA ${ }^{\mathrm{Lys} 3}$ was then investigated under similar conditions. Shifts and/or resolution of the fluorine resonances were observed for all compounds but with lower resolution. ${ }^{55}$

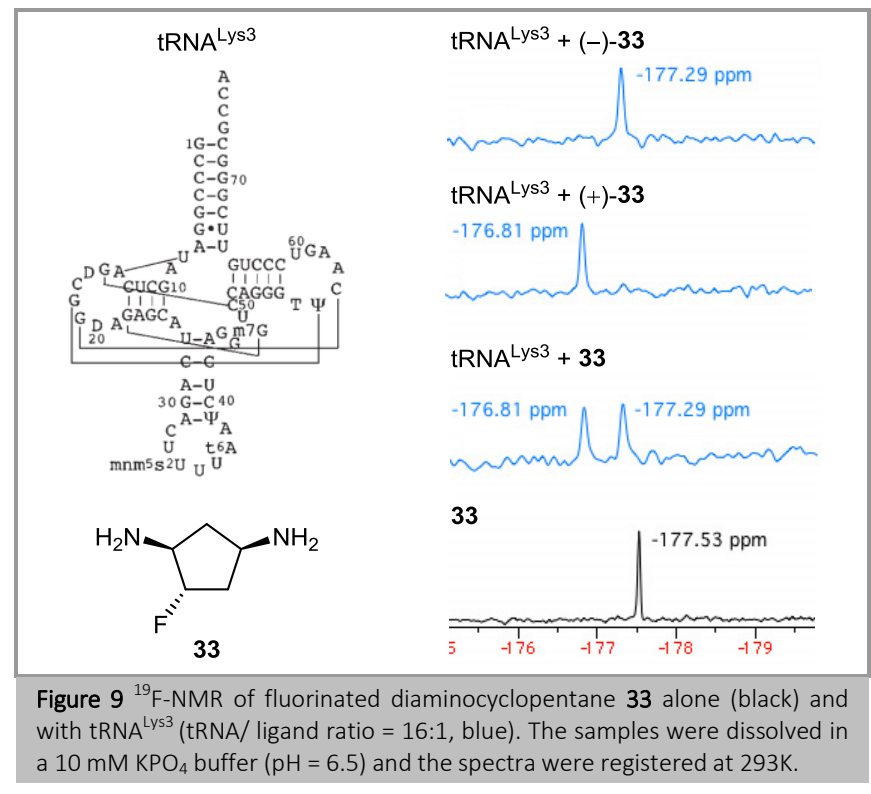

Interestingly, a smaller signal splitting was detected by fluorine NMR when the racemic probe $\mathbf{3 3}$ was mixed with a short oligonucleotide sequence mimicking the T-arm hairpin of tRNA ${ }^{\mathrm{Lys} 3}$, and no splitting was observed in the presence of the tRNA ${ }^{\text {Lys3 }}$ D-arm sequence, highlighting the sensitivity of fluorinated probes to the tertiary structure of RNA. Sensitivity to secondary structure was also confirmed by thermal denaturation experiments. ${ }^{55}$

Ligand-based fluorine NMR screening is a powerful method for binding constant measurements, popularized by Dalvit and coworkers. ${ }^{56}$ As 1,3 diamino cyclopentanes could mimic DOS, the central core of aminoglycosides, we assessed compound $\mathbf{3 3}$ as a fluorinated reporter against a 23-nucleotide hairpin mimicking the decoding A-site of $16 \mathrm{~S}$ ribosomal RNA, the natural target of aminoglycosides. ${ }^{57}$ Competition binding experiments were conducted by monitoring the ${ }^{19} \mathrm{~F}$ chemical shift of the reporter. As exemplified in Figure 10 with neamine, chemical shift variation as well as splitting modification could be observed by increasing competitor concentration, leading to the dissociation constant measurement of the non-fluorinated ligand.
Interestingly, observation of a splitting signal variation ensures that chemical shift variations are the direct consequence of the displacement of the racemic probe bound to its chiral target.

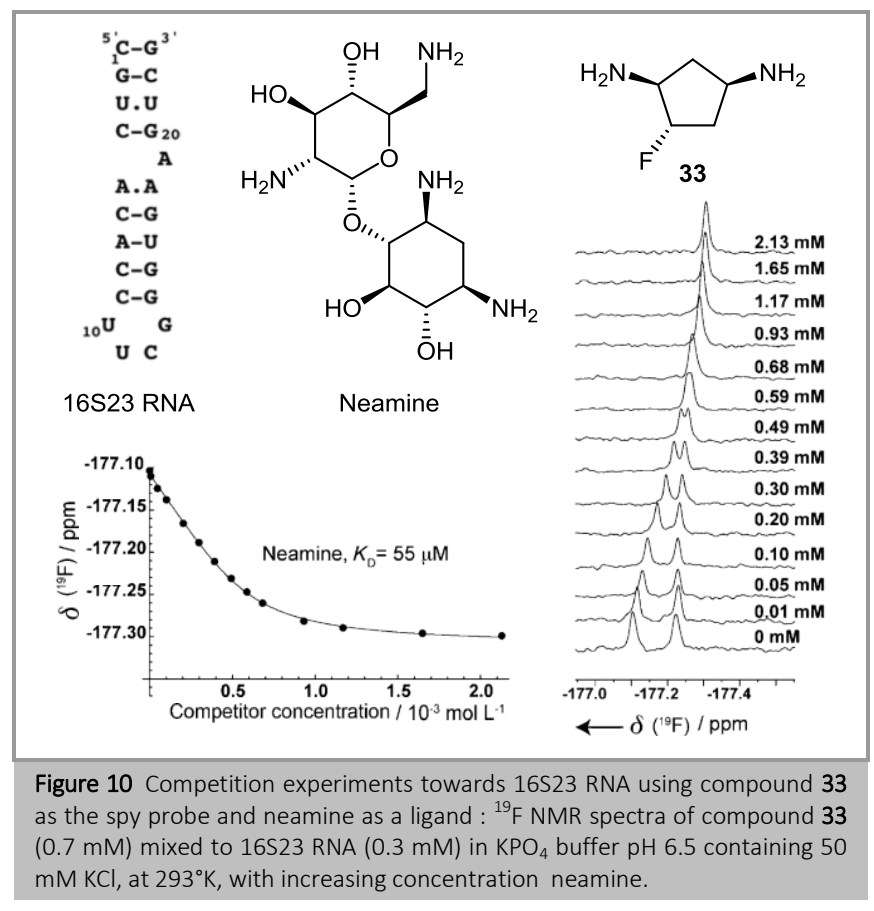

\section{$6 \quad$ Concluding remarks}

In this account article, we have described our efforts in setting up a general access to cyclic cis-1,3-diamines. We have shown that bicyclic hydrazines, easily available at a multigram scale, can lead to a large variety of five- and six-membered rings incorporating the cis-1,3-diamine motif in a few synthetic steps. All the transformations can be conducted on a large scale, and delivers intermediates and final substituted diamines in a regioand stereoselective fashion. This systematic chemical space exploration around the cyclic cis-1,3-diamine motif provides numerous valuable fragments and building blocks. We have illustrated the interest of this strategy in the field of RNA binders, with the design of ligands and probes. We have no doubt that potential applications of cyclic cis-1,3-diamines are not restricted to this field, and we hope that our work will contribute to further developments in other areas of research.

\section{Funding Information}

Part of the work conducted in our lab and reported in this account has been financed by MESR (ACI 2003), ANR (TrigerRNA), Université Paris Descartes and Satt IDFInnov.

\section{Acknowledgment}

CNRS , Université de Paris and Sanofi are acknowledged

\section{References}

(1) (a) Lucet, D.; Thierry Le Gall, T.; Mioskowski C. Angew. Chem. Int. Ed. 1998, 37, 2580. (b) Zhu, Y.; Cornwall, R. G.; Du, H.; Zhao, B.; Shi, Y. Acc. Chem. Res. 2014, 47, 3665. (c) Erik T. Michalson, E. T.; Szmuszkoviczin J. In Progress in Drug Research Jucker, E., Ed.; Birkhäuser Verlag: Basel, 1989, 135. (d) González-Sabín, J.; Rebolledo, F.; Goto, V. Chem. Soc. Rev. 2009, 38, 1916. 
(2) For a selected review on the synthesis of 1,3-diamines, see: Ji, X.; Huang, H. Org. Biomol. Chem. 2016, 14, 10557.

(3) (a) Guillon, J.; Hebert, G.; Dallemagne, P.; Leger, J.-M.; Vidaillac, C.; The, C.; Lisowski, V.; Rault, S.; Demotes-Mainard, J.; Jarry, C. J. Enzyme Inhib. Med. Chem. 2003, 18, 147. (b) Hurley, C.; Kulagowski, J.; Zak, M. PCT Int. Appl. WO 2013007768 A1, 2013. (c) Jia, Z. J.; Kane, B.; Xu, Q.; Bauer, S. M.; Song, Y.; Pandey, A.; Dick, R. PCT Int. Appl. WO 2013078468 A1, 2013. (d) Dorsch, D.; Hoelzemann, G.; Calderini, M.; Wegener, A.; Poeschke, O. PCT Int. Appl. WO 2014135244 A1, 2014. (e) Tsaklakidis, C.; Staehle, W.; Leuthner, B.; Czodrowski, P.; Fuchss, T. PCT Int. Appl. WO 2014202168 A1, 2014

(4) Mittendorf, J.; Kunisch, F.; Matzke, M.; Militzer, H.-C.; Schmidt, A.; Schonfeld, W. Bioorg. Med. Chem. Lett. 2003, 13, 433.

(5) Jarvis, M. F.; Yu, H.; McGaraughty, S.; Wismer, C. T.; Mikusa, J.; Zhu, C.; Chu, K.; Kohlhaas, K.; Cowart, M.; Lee, C.-H.; Stewart, A. O.; Cox, B. F.; Polakowski, J.; Kowaluk, E. A. Pain 2002, 96, 107.

(6) Qian, Y.; Conde-Knape, K.; Erickson, S. D.; Falcioni, F.; Gillespie, P.; Hakimi, I.; Mennona, F.; Ren, Y.; Salari, H.; So, S.-S.; Tilley, J. W. Bioorg. Med. Chem. Lett. 2013, 23, 4216.

(7) Simov, V.; Deshmukh, S. V.; Dinsmore, C. J.; Elwood, F.; Fernandez, R. B.; Garcia, Y.; Gibeau, C.; Gunaydin, H.; Jung, J.; Katz, J. D.; Kraybill, B.; Lapointe, B.; Patel, S. B.; Siu, T.; Su, H.; R. Young, J. R. Bioorg. Med. Chem. Lett. 2016, 26, 1803

(8) Ji, H.; Stanton, B. Z.; Igarashi, J.; Li, H.; Martasek, P.; Roman, L. J.; Poulos T. L.; Silverman, R. B. J. Am. Chem. Soc. 2008, 130, 3900.

(9) (a) Ogawa, A.; Shuto, S.; Tanaka, M.; Sasaki, T.; Mori, S.; Shigeta, S.; Matsuda, A. Chem. Pharm. Bull. 1999, 47, 1000. (b) Barnard, D. L.; Stowell, V. D.; Seley, K. L.; Hegde, V. R.; Das, S. R.; Rajappan, V. P.; Schneller, S. W.; Smee, D. F.; Sidwell, R. W. Antiviral Chem. Chemother. 2001, 12, 241.

(10) (a) Janssens, F. E.; Lacrampe, J. F. A.; Guillemont, J. E. G.; Venet, M. G.; Andries, K. J. L. M. PCT Int. Appl. WO 2001000615 A1, 2001. (b) Beaton, G.; Moree, W. J.; Rueter, J. K.; Dahl, R. S.; McElligott, D. L.; Goldman, P.; Demaggio, A. J.; Christenson, E.; Herendeen, D.; Fowler, K. W.; et al. PCT Int. Appl. WO 2003015785 A1, 2003. (c) Ogawa, A.; Ujjainwalla, F.; Chu, L.; Li, B.; Wei, L.; Xu, J.; Ok, H. O.; Lackner, A.; Kopka, I. E. PCT Int. Appl. WO 2011005608 A1, 2011. (d) Babu, S.; Bergeron, P.; Dragovich, P.; Dyke, H. J.; Gibbons, P.; Gradl, S.; Hanan, E.; Hurley, C.; Johnson, T.; Koehler, M.; et al PCT Int. Appl. WO 2011086053 A1, 2011. (e) Wohlfahrt, G.; Rummakko, P.; Karjalainen, A.; Passiniemi, M.; Pietikainen, P.; Haikarainen, A.; Vaisanen, E.; Tiainen, E. PCT Int. Appl. WO 2014202827 A1, 2014. (f) Burnett, D. A.; Vacca, J. PCT Int. Appl. WO 2018119395 A1; 2018.

(11) (a) Peng, F.; Chen, Y.; Chen, C.-Y.; Dormer, P. G.; Kassim, A.e; McLaughlin, M.; Reamer, R. A.; Sherer, E. C.; Song, Z. J.; Tan, L.; Tudge, M. T.; Wan, B.; Chung J. Y. L. J. Org. Chem. 2017, 82, 9023. (b) Chung, J. Y. L.; Scott, J. P.; Anderson, C.; Bishop, B.; Bremeyer, N.; Cao, Y.; Chen, Q.; Dunn, R.; Kassim, A.; Lieberman, D.; Moment, A. J.; Sheen, F.; Zacuto M. Org. Process Res. Dev. 2015, 19, 1760. (c) Chen, P.; Feng, D.; Qian, X.; Apgar, J.; Wilkening, R.; Kuethe, J. T.; Gao, Y.-D.; Scapin, G.; Cox, J.; Doss, G.; Eiermann, G.; He, H.; Li, X.; Lyons, K. A.; Metzger, J.; Petrov, A.; Wuc, J. K.; Xu, S. Weber, A. E.; Yan, Y.; Sinha Roy, R.; Biftu T. Bioorg. Med. Chem. Lett. 2015, 25, 5767.

(12) (a) Van Eis, M.; Schuler, W.; Von Matt, A.; Soldermann, N.; Monovich, L. G.; Gaul, C. PCT Int. Appl. WO 2008122614 A1, 2008 (b) Burger, M.; Lan, J. PCT Int. Appl. WO 2010026122 A1, 2010. (c) Pohlmann, J.; Stieger, M.; Reinelt, S.; Lane, H. PCT Int. Appl. WO 2016128465 A1, 2016.

(13) Padilla, F.; Bhagirath, N.; Chen, S.; Chiao, E.; Goldstein, D. M.; Hermann, J. C.; Hsu, J.; Kennedy-Smith, J. J.; Kuglstatter, A.; Liao, C.; Liu, W.; Lowrie, L. E.; Luk, K. C.; Lynch, S. M.; Menke, J.; Niu, L.; Owens, T. D O-Yang, C.; Railkar, A.; Schoenfeld, R. C.; Slade, M.; Steiner, S.; Tan, Y.-C.; Villaseñor, A. G.; Wang, C.; Wanner, J.; Xie, W.; Xu, D.; Zhang, X.; Zhou, M.; Lucas M. C. J. Med. Chem. 2013, 56, 1677.

(14) Takeuchi, J.; Ohkubo, A.; Yuasa, H. Chem. Asian J. 2015, 10, 586
(15) Yoshizawa, S.; Fourmy, D.; Eason, R. G.; Puglishi, J. D. Biochemistry 2002, 41, 6263.

(16) (a) Davis, B.D.; Chen, L.; Tai, P.C. Proc. Natl. Acad. Sci. U.S.A. 1986, 83, 6164. (b) Moazed, D.; Noller, H.F. Nature 1987, 327, 389. (c) Brodersen, D. E.; Clemons, W. M; Carter, A. P.; Morgan-Warren, R. J.; Wimberly, B. T.; Ramakrishnan, V. Cell 2000, 103, 1143. (d) Hermann, T. Biopolymers 2003, 70, 4. (e) Carnevali, M.; Parsons, J.; Wyles, D. L.; Hermann, T. ChemBioChem 2010 , 11, 1364.

(17) (a) Zhou, Y.; Chow, C.; Murphy, D. E.; Sun, Z.; Bertolini, T.; Froelich, J. M.; Webber, S. E.; Hermann, T.; Wall, D. Bioorg. Med. Chem. Lett. 2008, 18, 3369. (b) Cottin, T.; Pyrkotis, C.; Stathakis, C. I.; Mavridis, I.; Katsoulis, I. A.; Anastasopoulou, P.; Kythreoti, G.; Zografos, A. L.; Nahmias, V. R.; Papakyriakou, A.; Vourloumis, D. ChemBioChem 2011, $12,71$.

(18) For the preparation of five-membered rings, see: (a) Clark, M. A.; Goering, B. K.; Li, J.; Ganem B. J. Org. Chem. 2000, 65, 4058. (b) Kiss, L.; Forro, E.; Sillanpaeae, R.; Fueloep, F. J. Org. Chem. 2007, 72, 8786. (c) Kiss, L.; Forro, E.; Sillanpaeae, R.; Fueloep, F. Synthesis 2010, 153. For the synthesis of six-membered rings, see: (d) Schuerrle, K.; Beier, B.; Piepersberg, W. J. Chem. Soc., Perkin Trans. 1 1991, 2407. (e) Tan, Q.; Hayashi, M. Org. Lett. 2009, 3314. (f) Busscher, G. F.; Groothuys, S.; De Gelder, R.; Rutjes, F. P. J. T.; Van Delft, F. L. . J. Org. Chem. 2004, 69, 4477.

(19) (a) Monn, J. A.; Valli, M. J.; Massey, S. M.; Hao, J.; Reinhard, M. R.; Bures, M. G.; Heinz, B. A.; Wang, X.; Carter, J. H.; Getman, B. G.; Stephenson, G. A.; Herin, M.; Catlow, J. T.; Swanson, S.; Johnson, B. G.; McKinzie, D. L.; Henry S. S. J. Med. Chem. 2013, 56, 4442. (b) Baer, H. H.; Arai, I.; Radatus, B.; Rodwell, J.; Nguyen C. J. Can. Chem. 1987, 65, 1443. (c) Bauder, C. Org. Biomol. Chem. 2008, 6, 2952.

(20) (a) Verhelst, S. H. L.; Martinez, B. P.; Timmer, M. S. M.; Lodder, G.; Van der Marel, G. A.; Overkleeft, H. S.; Van Boom, J. H. J. Org. Chem. 2003, 68, 9598. (b) Verhelst, S. H. L.; Magnee, L.; Wennekes, T.; Wiedenhof, W.; Van Der Marel, G. A.; Overkleeft, H. S.; Van Boeckel, C. A. A.; Van Boom, J. H. Eur. J. Org. Chem. 2004, 2404. (c) Verhelst, S. H. L.; Wiedenhof, W.; Ovaa, H.; van der Marel, G. A.; Overkleeft, H. S.; van Boeckel, C. A. A.; van Boom, J. H. Tetrahedron Lett. 2002, 43, 6451. (d) Verhelst, S. H. L.; Wennekes, T.; van der Marel, G.t A.; Overkleeft, H. S.; van Boeckel, C. A. A.; van Boom, J. H. Tetrahedron 2004, 60, 2813.

(21) (a) Couladouros, E. A.; Constantinou, K.; Georgiadis, M. P.; Kokotos, G. Carbohydr. Res. 1994, 254, 317. (b) Trost, B. M.; Malhotra, S. Chem. Eur. J. 2014, 20, 8288. (c) De Almeida, M. V.; Da Silva, E. T.; Le Hyaric, M.; Machado, A. S.; De Souza, M. V. N.; Santiago, R. M. J. Carbohydr. Synth. 2003, 22, 733. (d) Nakajima, M.; Kurihara, N.; Hasegawa, A.; Kurokawa, T. Justus Liebigs Ann. Chem. 2006, 689, 243. (e) Da Silva, E. T.; Le Hyaric, M.; Machado, A. S.; De Almeida, M. V. Tetrahedron Lett. 1998, 39, 6659.

(22) Zhou, H.; Topiol, S. W.; Grenon, M.; Jimenez, H. N.; Uberti, M. A.; Smith, D. G.; Brodbeck, R. M.; Chandrasena, G.; Pedersen, H.; Madsen, J. C.; Doller, D.; Li, G Bioorg. Med. Chem. Lett. 2013, 23, 1398.

(23) (a) Kitagawa, I.; Kadota, A.; Yoshikawa, M. Chem. Pharm. Bull. 1978, 26, 3825. (b) Yoshikawa, M.; Kamigauchi, T.; Ikeda, Y.; Kitagawa, I. Chem. Pharm. Bull. 1981, 29, 2582. (c) Yoshikawa, M.; Ikeda, Y.; Takenaka, K.; Torihara, M.; Kitagawa, I. Chem. Lett. 1984, 12, 2097. (d) Yoshikawa, M.; Ikeda, Y.; Kayakiri, H.; Kitagawa, I. Heterocycles 1982, 17, 209. (e) Wolfrom, M. L.; Olin, S. M.; Polglase, W. J. J. Am. Chem. Soc. 1950, 72, 1724. (f) Suami, T.; Ogawa, S.; Tanno, N.; Suguro, M.; Rinehart, K. L. Jr. J. Am. Chem. Soc. 1973, 95, 8734. (g) Ogawa, S.; Rinehart, K. L. Jr.; Kimura, G.; Johnson, R. P. J. Org. Chem. 1974, 39, 812. (h) Hasegawa, A.; Sable, H. Z. Tetrahedron 1969, 25, 3567. (i) Yoshikawa, M.; Ikeda, Y.; Kayakiri, H.; Takenaka, K.; Kitagawa, I. Tetrahedron Lett. 1982, 23, 4717.

(24) (a) Garsi, J.-B.; Vece, V.; Sernissi, L.; Auger-Morin, C.; Hanessian, S.; McCracken, A. N.; Selwan, E.; Ramirez, C.; Dahal, A.; Ben Romdhane, N.; Finicle, B. T.; Edinger, A. L. Bioorg. Med. Chem. Lett. 2019, 29, 2681. (b) Busscher, G.e F.; Rutjes, F. P. J. T.; Van Delft, F. 
L. Tetrahedron Lett. 2004, 45, 3629. (c) Ohlmeyer, M.; Kastrinsky, D. PCT Int. Appl. WO 2017044572 A1, 2017.

(25) (a) Tomkins, P.; Muller, T. E. ChemCatChem 2018, 10, 1438. (b) Merten, G. J.; Neis, C.; Stucky, S.; Huch, V.; Rentschler, E.; Natter, H.; Hempelmann, R.; Stoewe, K.; Hegetschweiler, K. Eur. J. Inorg. Chem. 2012, 31. (c) Hegetschweiler, K.; Erni, I.; Schneider, W.; Schmalle, H. Helv. Chim. Acta 1990, 73, 97. (d) Parker, D.; Senanayake, K.; Vepsailainen, J.; Williams, S.; Batsanov, A. S.; Howard J. A. K. J. Chem. Soc., Perkin Trans. 2 1997, 8, 1445. (e) Dijkstra, D. Recl. Trav. Chim. Pays-Bas 1968, 87, 161. (f) Baer, H. H.; Yu, R. J. Tetrahedron Lett. 1967, 9, 807.

(26) (a) Schwesinger, R.; Prinzbach, H. Angew. Chem. Int. Ed. 1975, 14, 630. (b) Prinzbach, H.; Kefier, R.; Schwesinger, R. Angew. Chem. Int. Ed. 1975, 14, 632. (c) Jiao, G.-S.; Cregar, L.; Goldman, M. E.; Millis, S. Z.; Tang, C. Bioorg. Med. Chem. Lett. 2006, 16, 1527. (d) Kavadias, G.; Velkof, S.; Belleau, B. Can. J. Chem. 1978, 56, 404. (e) Suami, T.; Ogawa, S.; Uchino, H.; Funaki, Y. J. Org. Chem. 1975, 40, 456. (f) Ogawa, S.; Ueda, T.; Funaki, Y.; Hongo, Y.; Kasuga, A.; Suami, T. J. Org. Chem. 1977, 42, 3083. (g) Rattray, N. J. W.; Zalloum, W. A.; Mansell, D.; Latimer, J.; Jaffar, M.; Bichenkova, E. V.; Freeman, S. Tetrahedron 2013, 69, 2758.

(27) Chenevert, R.; Jacques, F. Tetrahedron: Asymm. 2006, 17, 1017.

(28) (a) Haviv, F.; Belleau, B. Can. J. Chem. 1978, 56, 2677. (b) Vourloumis, D.; Winters, G. C.; Simonsen, K. B.; Takahashi, M.; Ayida, B. K.; Shandrick, S.; Zhao, Q.; Han, Q.; Hermann, T. ChemBioChem 2005, 6, 58.

(29) (a) Hasegawa, A.; Sable, H. Z. Tetrahedron 1969, 25, 3567. (b) Qiao, J.-Bao; Z., Yu-Ming; Gu, P. Org. Lett. 2016, 18, 1984.

(30) (a) Suami, T.; Ogawa, S.; Naito, S.; Sano, H. J. Org. Chem. 1968, 33, 2831. (b) Ogawa, S.; Ueda, T.; Funaki, Y.; Hongo, Y.; Kasuga, A.; Suami, T. J. Org. Chem. 1977, 42, 3083. (c) Pang, L.-J.; Wang, D.; Zhou, J.; Zhang, L.-H.; Ye, X.-S. Org. Biomol. Chem. 2009, 7, 4252. (d) Fielden, J. Sprott, J.; Cronin, L. New. J. Chem. 2005, 29, 1152. (e) Suami, Tetsuo; Ogawa, Seiichiro Bull. Chem. Soc. Jpn 1965, 38, 2026.

(31) Duan, J. J.-W.; Lu, Z.; Jiang, B.; Yang, B. V.; Doweyko, L. M.; Nirschl, D. S.; Haque, L. E.; Lin, S.; Brown, G.; Hynes, J. et al Bioorg. Med. Chem. Lett. 2014, 24, 5721.

(32) (a) Jaramillo, D.; Buck, D. P.; Collins, J. G.; Fenton, R. R.; Stootman, F. H.; Wheate, N. J.; Aldrich-Wright, J. R. Eur. J. Inorg. Chem. 2006, 839. (b) Gillard, R. D.; Newman, P. D.; Vagg, R. S.; Williams, P. A. Inorg. Chim. Acta 1995, 233, 79. (c) Zhou, Z.; Li, Z.; Li, K.; Yang, Z; Zhao, G.; Wang, L.; Zhou, Q.; Tang, C. Phosphorus Sulfur Silicon Relat. Elem. 2003, 178, 1771. (d) Yang, Z.-H.; Wang, L.-X.; Zhou, Z.H.; Zhou, Q.-L.; Tang, C.-C. Tetrahedron: Asymm. 2001, 12, 1579. (e) Menger, F. M.; Bian, J.; Azov, V. A. Angew. Chem. Int. Ed. 2002, 41, 2581. (f) Bowen, T.; Roy P. Planalp, R. P.; Brechbiel M. W. Bioorg. Med. Chem. Lett. 1996, 6, 807.

(33) Ghisletta, M.; Jalett, H. P.; Gerfin, T.; Gramlich, V.; Hegetschweiler, K. Helv. Chim. Acta 1992, 75, 2233. (b)

(34) (a) Mellor, J. M.; Smith, N. M. J. Chem. Soc., Perkin Trans. 1 1984, 2921. (b) Grabowski S.; Armbruster, J.; Prinzbach H. Tetrahedron Lett. 1997, 38, 5485. (c) Zaragoza Doerwald, F.; Hanselmann, P.; Zollinger, D. Eur. Pat. Appl. EP 2394982 A1, 2011. (d) Dey, R. T.; Sarkar, T. K. J. Org. Chem. 2010, 75, 4521.

(35) MacKenzie, J. C. J.; Rodgman, A.; Wright, G. F. J. Org. Chem. 1952, $17,1666$.

(36) Bournaud, C.; Bonin, M.; Micouin, L. Org. Lett. 2006, 8, 3041.

(37) (a) Perez Luna, A.; Ceschi, M.-A.; Bonin, M.; Micouin, L.; Husson, H.-P.; Gougeon, S.; Estenne-Bouhtou, G.; Marabout, B.; Sevrin, M.; George, P. J. Org. Chem. 2002, 67, 3522. (b) Perez Luna, A.; Bonin, M.; Micouin, L.; Husson, H.-P. J. Am. Chem Soc. 2002, 124, 12098.
(38) Bunlaksananusorn, T.; Perez Luna, A.; Bonin, M.; Micouin, L.; Knochel, P. Synlett 2003, 2240.

(39) Pasco, M.; Moumné, R.; Lecourt, T.; Micouin, L. J. Org. Chem. 2011, 76, 5137.

(40) (a) Smart, B. E. J. Fluorine Chem. 2001, 109. (b) Purser, S.; Moore, P. R.; Gouverneur, V. Chem. Soc. Rev. 2008, 37, 320. (c) Morgenthaler, M.; Schweizer, E.; Hoffmann-Roder A.; Benini, F.; Martin, R. E.; Jaeschke, G.; Wagner, B.; Fischer, H.; Bendels, S.; Zimmerli, D.; Schneider, J.; Diederich, F.; Kansy, M.; Muller, K. ChemMedChem 2007, 2, 1100. (d) Muller, K.; Faeh, C.; Diederich, F. Science 2007, 317, 1881.

(41) Blond, A.; Turcaud, S.; Lecourt, T.; Micouin, L. ACS Omega 2018, 3, 15302.

(42) Carnevali, M.; Parsons, J.; Wyles, D. L.; Hermann, T. ChemBioChem 2010, 11, 1364.

(43) (a) Blond, A.; Dockerty, P.; Alvarez, R.; Turcaud, S.; Lecourt, .T.; Micouin, L. J. Org. Chem. 2013, 78, 12236. (b) Micouin, Laurent; Blond, A.; Calvez, V.; Marcellin, A.-G.; Soulie, C.; Corrot, E. PCT Int. Appl. WO 2015181387 A1, 2015.

(44) (a) Mattick, J. S. Nat. Rev. Gen. 2004, 3, 316. (b) Mattick, J. S. Science 2005, 309, 1527. [c] Esteller, M. Nat. Rev. Genet. 2011, 12, 861.

(45) (a) Zaman, G. J. R ; Michiels, P. J. A.; van Boeckel, C. A. A. Drug Discovery Today 2003, 8, 297. (b) Gallego, J.; Varani, G. Acc. Chem. Res. 2001, 34, 836. (c) Thomas, J. R.; Hergenrother, P. J. Chem. ReV. 2008, 108, 1172. (d) Warner, K. D.; Hajdin, C. E.; Weeks, K. M. Nat. Rev. Drug Discov. 2018, 17, 547. (e) Costales, M. G.; Childs-Disney, J. L.; Haniff, H. S.; Disney, M. D. J. Med. Chem. 2020, ASAP, doi: 10.1021/acs.jmedchem.9b01927

(46) Luedtke, N. W.; Tor Y. in Small Molecule DNA and RNA Binders: FromSynthesis to Nucleic Acid Complexes, Vol. 1 Demeunynck, M.; Bailly, C.; Wilson, W. D. Eds.. Wiley-VCH, Weinheim: 2003.

(47) Marquet, R.; Isel, C.; Ehresmann, B. Biochimie 1995, 77, 113.

(48) Tisné,C.; Guillière, F.; Dardel, F. Biochimie 2005, 87, 885.

(49) Benas, P.; Bec, G.; Keith, G.; Marquet, R.; Ehresmann, C.; Ehresmann, B.; Dumas, P. RNA 2000, 6, 1347.

(50) (a) Tisné, C.; Roques, B. P.; Dardel, F. J. Mol. Biol. 2001, 305-314, 443. (b) Tisné, C.; Roques, B. P.; Dardel, F. J. Mol. Biol. 2004, 279, 3588.

(51) (a) Rees, D.C.; Congreve, M.; Murray, C.; Carr, R. Nat. Rev. Drug Discov. 2004, 3, 660 (b) Jahnke, W.; Erlanson , D. A.; Fragmentbased approaches in drug discovery, Wiley- VCH, 34, 2006. (c) Murray, C. W.; Rees, D. C. Nat. Chem. 2009, 1, 187. (d) Jhoti, H.; Williams, G.; Rees, D. C.; Murray, C. W. Nat. Rev. Drug Discov. 2013, 12,644 .

(52) (a) Chung, F.; Tisne, C.; Lecourt, T.; Dardel, F.; Micouin, L. Angew. Chem. Int. Ed. 2007, 46, 4489. (b) Chung, F.; Tisne, C.; Lecourt, T.; Seijo, B.; Dardel, F.; Micouin, L. Chem. Eur. J. 2009, 15, 7109.

(53) (a) Zhang, L.; Chen, X.; Xue, P.; Sun, H. H. Y.; Williams, I. D.; Sharpless, K. B.; Fokin V. V.; Jia, G. J. Am. Chem. Soc. 2005, 127, 15998. (b) Boren, B. C.; Narayazn, S.; Rasmussen, L. K.; Zhang, L.; Zhao, H.; Lin, Z.; Jia G.; Fokin, V. V. J. Am. Chem. Soc. 2008, 130, 8923.

(54) Moumné, R.; Larue, V.; Seijo, B.; Lecourt, T.; Micouin, L.; Tisne, C. Org. Biomol. Chem. 2010, 8, 1154.

(55) Moumné, R.; Pasco, M.; Prost, E.; Lecourt, T.; Micouin, L.; Tisne, C. J. Am. Chem. Soc. 2010, 132, 13111.

(56) Dalvit, C.; Vulpetti, A. J. Med. Chem. 2019, 62, 2218.

(57) Lombès, T.; Moumné, R.; Larue, V.; Prost, E.; Catala, M.; Lecourt, T.; Dardel, F.; Micouin, L.; Tisné, C. Angew. Chem. Int. Ed. 2012, 51, 9530.

\section{Biosketches}




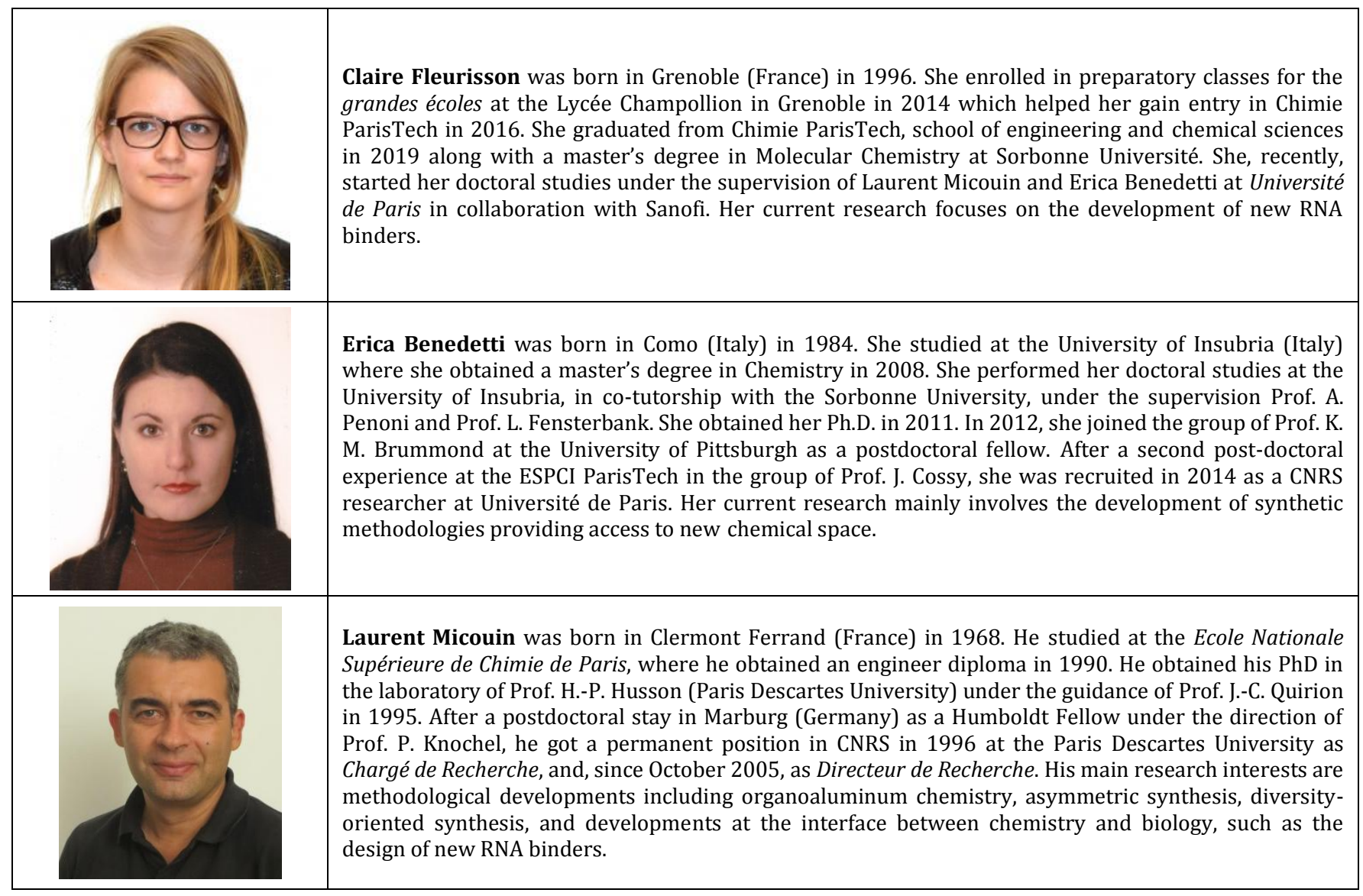

